\title{
İzmir İlinde Elektrikli Kara Araçları için Güneş Enerjisi Destekli Bir Şarj İstasyonunun Tasarlanması
}

\author{
Atahan Çobanoğlu ${ }^{1}$, Gökhan Demirkıran ${ }^{2 *}$, Mustafa Güneş ${ }^{3}$ \\ ${ }^{1}$ Ege Üniversitesi, Güneș Enerjisi Enstitüsü, İzmir, Türkiye (ORCID: 0000-0001-6789-4051), atahancobanoglu@gmail.com \\ ${ }^{2 *}$ Yaşar Üniversitesi, Mühendislik Fakültesi, Elektrik-Elektronik Mühendisliği Bölümü, İzmir, Türkiye (ORCID: 0000-0002-0076-6036), \\ gokhan.demirkiran@yasar.edu.tr \\ ${ }^{3}$ Ege Üniversitesi, Güneș Enerjisi Enstitüsü, İzmir, Türkiye (ORCID: 0000-0001-7042-3605), mustafa.gunes@ege.edu.tr
}

(İlk Geliş Tarihi 7 Ağustos 2020 ve Kabul Tarihi 31 Ocak 2021)

(DOI: 10.31590/ejosat.777874)

\begin{abstract}
ATIF/REFERENCE: Çobanoğlu, A., Demirkıran, G., \& Güneş, M. (2021). İzmir İlinde Elektrikli Kara Araçları için Güneş Enerjisi Destekli Bir Şarj İstasyonunun Tasarlanması. Avrupa Bilim ve Teknoloji Dergisi, (21), 635-648.

$\ddot{O} z$

Ulaşım alanındaki enerji ihtiyacı gün geçtikçe artmaktadır. Ulaşım sektörünün enerji kullanımındaki payı görece fazla olduğu için son yıllarda elektrikli araç ve şarj istasyonlarına olan yatırımlar ivme kazanmıştır. Bu bağlamda, şarj istasyonlarının güneş enerjisi gibi yenilenebilir kaynaklardan enerjilerini üreterek şebekeye olan yükü ve araç dolum maliyetlerini azaltması beklenmektedir. Bu çalışmada, İzmir ili için alışveriş merkezlerinde geçirilen süreler, mevcut elektrikli araç sayısı ve şarj istasyonu sayısı dikkate alınarak fotovoltaik panel ile desteklenmiş şebekeye bağlı bir elektrikli araç şarj istasyonunun yenilenebilir enerji, talep ve güç dengesi altsistemleri kullanılarak simülasyon modeli MATLAB $\backslash$ Simulink ortamında oluşturulmuştur. Elektrikli aracın geliş zamanı, istasyonda ne kadar kalacağı ve bataryasının doluluk oranı literatür ve gerçek verilere uygun olarak rassal değişken olarak modellenmiştir. Farklı boyutlandırılmış güneş enerjisi destekli elektrik araç şarj istasyonlarının önümüzdeki 25 seneyi kapsayacak şekilde maliyet analizi yapılmıştır. Bataryaların kullanılmadığı durumda sistemin kendini 5 seneden az bir sürede amorti ettiği, batarya kullanılan sistemlerin ise kendini amorti edemediği ancak şebekeye binen yükün azaltılması yoluyla şebeke güvenliğinin sağlanmasına bataryasız sistemlere göre daha yüksek katkıda bulunduğu anlaşılmıştır.
\end{abstract}

Anahtar Kelimeler: Elektrikli Araç, Güneş Enerjisi, Fotovoltaik, Şarj İstasyonu.

\section{Design of a Solar-Assisted Charging Station for Electric Vehicles in İzmir}

\begin{abstract}
The energy demand in the field of transportation is increasing day by day. Investments in electric vehicles and charging stations have gained momentum in recent years as the transportation sector has a relatively large share in energy use. In this context, charging stations are expected to generate their energy from renewable sources such as solar energy and reduce the load on the grid and vehicle charging costs. In this study, a simulation model of a charging station connected to the grid supported by photovoltaic panel is created by MATLAB $\backslash$ Simulink based on the times spent in shopping centers, the number of vehicles and charging stations available for İzmir. This model consists of renewable (solar) energy, demand and power balance subsystems. The arrival time of the electric vehicle, the duration which it will stay at the station and the battery's state of charge measure are all treated as random processes. The cost analysis of different sized solar-assisted electric vehicle charge stations has been carried out for 25 years. Additionally, the effect on reducing the excessive load on the grid is investigated. It has been found that the system pays for itself in less than 5 years when the batteries are not used, and the systems using batteries cannot pay for itself, but they contribute more to the security of the network by reducing the load on the network compared to the systems without batteries.
\end{abstract}

Keywords: Electric Vehicle, Photovoltaic, Solar Energy, Charging Station.

* Sorumlu Yazar: gokhan.demirkiran@yasar.edu.tr 


\section{Giriş}

2004 y1lından 2018 yılına kadar Türkiye'deki enerji tüketiminin ulaştırma sektöründeki payı \%20'den yaklaşık \%26'ya yükselmiştir (EİGM, 2020). Ulaşım sektöründeki enerjinin büyük bir bölümünün fosil yakıt kullanan araçların motorları (içten yanmalı motorları) tarafından harcandığ gözönüne alındığında, ulaşım sektörünün elektrifikasyonu yani Elektrikli Araçların (EA'ların) yaygınlaştırılması, kentlerdeki hava kirliliğini azaltmak için etkili bir yol olarak görülmektedir (Saygın ve ark., 2019a). EA'lar özellikle devletlerin ve otomobil üreticilerinin teşviğiyle giderek yaygınlaşmakta ve hızlı şarj istasyonlarının da geliştirilmesi ile birlikte kullanılabilirliği giderek artmaktadır. Ancak, hızlı şarj istasyonlarının kısa aralıklar ile yüksek güç talebi şebeke voltajında dengesizliklere yol açmaktadır (Shaukat ve ark., 2018). Bu bağlamda, EA şarj istasyonları tarafından şebekeye bindirilen yükü azaltacak çözümlere ihtiyaç vardır (Peng, Zou, \& Lian, 2017).

$\mathrm{Bu}$ çözümler özellikle EA şarj istasyonları tarafından şebekeye aksettirilen tepe yüklerin azaltılması amacıyla, iş yerleri veya alışveriş merkezleri (AVM'ler)gibi toplu yerlerde, EA'ların şarj sıralarını belirleme, takvimleme gibi çalışmalar üzerine yoğunlaşmıştır (Liu ve ark.., 2015; Zheng ve ark., 2019). Örneğin, park yerlerinin şehir içinde nasıl dağıtılması gerektiği ve EA'ların şarj/deşarjlarının nasıl takvimlenmesi gerektiği, şebeke en az etkilenecek şekilde bir eniyileme modeli olarak sunulabilir (Mohammadi Landi, Mohammadi, and Rastegar 2018). Yenilenebilir enerji kaynaklarının rassal doğasına uygun EA şarj takvimlemesinin de şebeke tepe yüklerini azaltıcı etkisi vardır (Jiang ve ark., 2017). Enerji kaynaklarının yönetimi haricinde, insan psikolojisine dayalı olarak EA sahiplerinin katıldığı bir dinamik fiyatlandırma modeli ile de, şebekeye binen yük dengelenebilir (Dong ve ark., 2018). Ayrıca, EA'ların prize takılı oldukları süre boyunca şebekenin ihtiyaç duyduğu anda potansiyel bir enerji kaynağı olarak kullanılması teknolojileri (V2G: Vehicle-to-Grid) ve bunların işletilmesi ile ilgili çalışmalar, şebekedeki voltaj dengesizliklerini azaltabilme potansiyeline sahiptir (Mwasilu ve ark., 2014) (Jian ve ark., 2015). Örneğin, V2G teknolojisi tepe talep taşıma ve yük kaydırma gibi stratejilere olanak sağlamaktadır (Liang ve ark., 2019).

Yukarıda bahsedilen çalışmalar, bir akıllı şebeke entegrasyonuna, akıllı algoritmik yaklaşımlara ve güçlü iletişim teknolojilerine ihtiyaç duymaktadır (Mwasilu ve ark., 2014) (Tuballa \& Abundo, 2016). Ancak, akıllı şebekeler henüz geliştirilme aşamasında olduğundan, bu çalışmaların iş modellerine dönüştürülmesi en azından Türkiye'de şu anda mümkün görünmemektedir. Ayrıca, çoğu çalışma EA şarj istasyonlarının yenilenebilir enerji ile desteklenmesi durumlarını Amerika ve Avrupa gibi şehirleşmenin daha yatay olduğu, dolayısıyla müstakil evlerin ve garajların yeterli çoklukta olduğu yerleri dikkate almışlardır. Türkiye'de ise Amerika ve Avrupa kıtasının geneline göre müstakil ev sayısı oldukça kısıtlıdır (Saygın ve ark. 2019b). Dolayısıyla, yeme-içme yerlerinin yakınlarında, AVM'lerde şarj istasyonlarının kurulumunun teşvik edilmesi Türkiye'ye özgü öncelik verilecek çözümlerin başında gelmektedir (Resmî Gazete, 2018). Bu bağlamda, Türkiye'de ev dışında kurulacak şarj altyapılarına, bunların işletilmesine ve yenilenebilir enerji ile desteklenmesine yönelik daha fazla çalışmaya gereksinim duyulmaktadır.

$\mathrm{Bu}$ bilgilerin 1şığında bu çalışmanın amacı, gelecekte ülkemizde de yaygın olarak kullanılacağı düşünülen elektrikli e-ISSN: 2148-2683 kara araçları için örnek oluşturabilecek güneş enerjisi destekli bir şarj istasyonunun tasarımını yapmak ve bu tasarımın farklı senaryolar için talep ve maliyet analizleri ile şebeke güvenliğine etkisini incelemektir. Bu doğrultuda İzmir ili Karşıyaka ilçesindeki bir AVM'ye kurulduğu varsayılan fotovoltaik (FV) enerji destekli bir EA şarj istasyonunun önümüzdeki 25 sene boyunca şebekeye binen yükün azaltılmasındaki etkileri ve böyle bir yerin işletilmesinin yatırım anlamında maliyet analizi benzetim yoluyla yapılmıştır. 25 yıllık benzetim sonucunda, kurulması planlanan sistem ile ilgili amorti süreleri, kazanç ve şebekeye binen yükün azaltılmasına olan katkısı rapor edilmiştir. Yapılan benzetim çalışmasının gerçeği olabildiğince yansıtabilmesi için üzerinde durulmuş önemli hususlar ile kabuller şunlardır:

Dünyadaki EA sayısındaki artış oranına ve geçmiş 10 senelik (2007-2016 yılları arasında) fotovoltaik enerji potansiyeline uygun olarak, kurulumundan sonraki 25 sene boyunca sistemin çalışmasının benzetimi yapılmıştır. Benzetimin çok yönlü olarak olabildiğince gerçeği yansıtabilmesi için ayrıca şu değişkenler rassal olarak belirlenmiş ve uygun şekilde benzetime entegre edilmiştir: i) EA geliş sıklıkları Google Maps platforumundan (Google, 2009), AVM'nin günlük ve saatlik popülarite grafiğine uygun olarak ve EA'ların seneler içindeki yaygınlığının artışı (IEA, 2018) çalışması baz alınarak üretilmiştir; ii) AVM'de kalış süreleri (Konyalıŏlu 2014)'teki çalışmaya uygun olarak üretilmiştir; iii) EA'ların günlük olarak harcadığı enerji (Wang et al. 2019) çalışmasına uygun olarak belirlenmiştir. Sistemde hesaplamalar için kullanılması planlanan elektrik alış ve satış fiyatı tek zamanlı olarak güncel haliyle Enerji Piyasası Düzenleme Kurumu (EPDK) sitesinden elde edilmiştir (EPDK, 2019). Fakat satış kurallarının ve fiyatının belirlenmesinde ise 'Elektrik Piyasasında Lisanssız Elektrik Üretim Yönetmeliği' (Resmî Gazete, 2019a) ve "Yenilenebilir Enerji Kaynaklarının Elektrik Enerjisi Üretimi Amaçlı Kullanımına İlişkin Kanun ile Elektrik Piyasası Kanunu” (Resmî Gazete, 2019b) kullanılmıştır.

Çalışmada, Bölüm 2'de adım adım sistemin simulasyon modelinin tüm bileşenleri oluşturulmuş olup, Bölüm 3 'te ise simulasyon modeli koşturularak maliyet analizi ve şebekeye binen yükün analizi yapılmıştır. Bölüm 4'te bulgular özetlenmiş ve öneriler sunulmuştur.

\section{Sistem Bileșenlerinin Benzetim Modelinin Oluşturulması}

Ele aldığımız benzetim sistemi, FV enerji, talep ve güç dengesi olmak üzere üç altsistemden oluşmaktadır. Sistemin girdileri, anlık FV enerji ve anlık talep, çıktısı ise güç dengesinden çıkan rapordur. $\mathrm{Bu}$ rapor, sistemin enerji kullanımı ile ilgili bilgileri içermektedir. Sistem şu şekilde kurgulanmıştır:

- $\quad$ FV destekli EA şarj istasyonuna FV enerji güne ve günün saatine bağlı olarak rassal olarak gelmektedir.

- AVM'ye güne ve günün saatine bağlı ve rassal olarak EA gelmektedir.

- Şehir içindeki EA sayısı Uluslarası Enerji Ajansı (International Energy Agency [IEA], 2018) raporuna göre artmaktadır. Rassal olarak gelen araçların sayısı da bununla orantılı olarak artmaktadır.

- Bu çalışmanın yapıldığı tarihte İzmir'de yaklaşık 100 EA bulunmaktadır ve Şubat 2019 ayı içerisinde 700 kWh'lik enerji talep edilmiştir. Bu oranın, AVM içerisindeki EA popülasyonunda 
da korunduğu varsayılmıştır. Ancak, yazarlar olarak AVM içerisinde kurulmuş olan şarj istasyonlarının, şehir içindeki şarj istasyonlarına göre daha fazla müşteri çekeceğini düşünmekteyiz. Çünkü, menzil kaygısı sebebiyle AVM'de bulunulan süre içerisinde EA sahipleri, bataryaları boş olmasa dahi şarj istasyonuna park etmek isteyebilir. $\mathrm{Bu}$ durumda, bu makalede sistem ile ilgili öngörülen kazanç, sistemin elde edebileceği minimum kazanç olarak değerlendirebilir.

\subsection{Fotovoltaik Girdi}

FV güç verisini elde etmek için Avrupa Komisyonu tarafindan kurulan FV Coğrafi Bilgi Sistemi (PhotoVoltaic Geographical Information System)'nden (PVGIS) yararlanılmıştır (European Commission, 2019). Çevrimiçi bir web uygulaması olan PVGIS güneş 1şınımı haritaları ve hassas FV performans verileri sağlamaktadır. Verilerin oluşturulması ile ilgili bilimsel ve hesapsal prosedür web sitesinde şeffaf bir şekilde sunulmaktadır. Bununla birlikte, bu sistem çok sayıda çıktıya sahip bir araştırma projesidir ve ortak araştırma merkezi içindeki ve dışındaki diğer birçok projeye verilerle katkıda bulunmuştur (European Commission, 2019).

Saat-saat $1 \mathrm{kWp}$ (kiloWatt-peak) kurulu güç için FV güç üretim verisi 2007-2016 yılları arasında İzmir ili Karşıyaka ilçesindeki bir AVM konumu için PVGIS web sitesinden alınmıştır. Bu yılların aritmetik ortalaması alınarak 1 yıllık tek bir ortalama üretim verisi oluşturulmuş ve referans üretim verisi olarak kabul edilmiştir. $1 \mathrm{kWp}$ 'lik referans üretim verisi Şekil 1.a'da gösterilmiştir. Boyutlandırma çalışmaları kapsamında, benzetim sırasında bu referans verinin katları kullanılacaktır (Şekil 1.b). Önümüzdeki 25 sene boyunca üretim gücünün bu şekilde senelik olarak tekrarlanacağı kabul edilmiştir.

Ülkemizde bulunan ve satılmaya devam eden EA'ların fiyat uygunluğu ve batarya kapasiteleri, AVM'lerde çoğunlukla geçirilen sürenin genelde 1-3 saat olması (Konyalığlu, 2014) göz önüne alınarak, her araca ve fiyat-performans olarak uygunluğu da ön planda olduğu için oluşturulacak sistemde şarj istasyonunun $11 \mathrm{~kW}$ olmasına karar verilmiştir (Şarj istasyonları $22 \mathrm{~kW}$ veya $11 \mathrm{~kW}$ olmaktadır). $10 \mathrm{~kW}$ 'lik bir InfiniSolar hibrit evirici, 11 kW'lık şarj istasyonunu limitleri dahilinde karşılayabilmektedir. (InfiniSolar, 2019). 2 veya 3 tane hibrit evirici uygun şekilde

a)

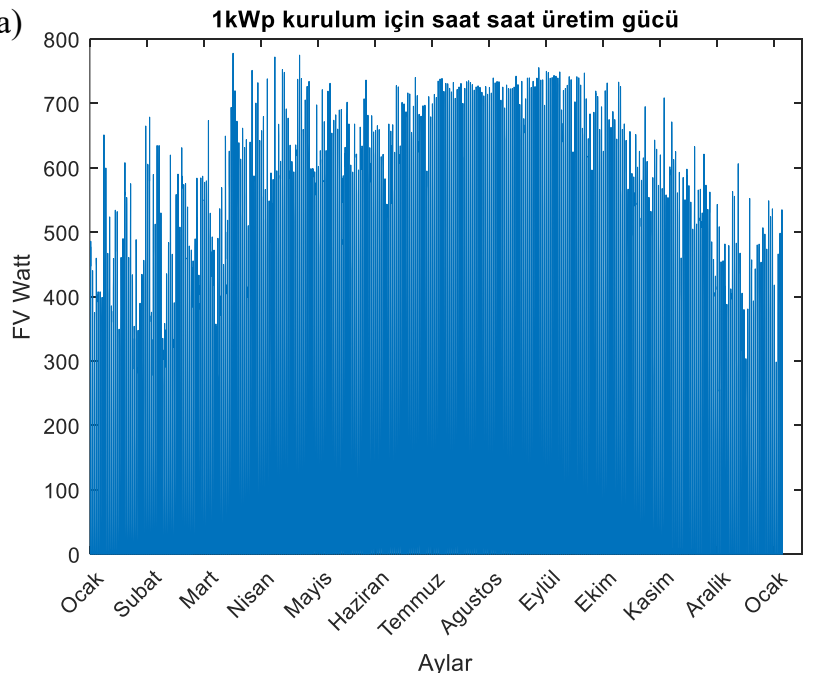

bağlanıp, daha fazla evirme gücü elde edilebilir. Ancak, bu sistem maliyetlerini artıracaktır.

Seçilen 10 kW'lık eviriciye bağlanabilecek FV güçleri Tablo 1'de gösterilmiştir. Eviriciye toplamda 6 tane farklı boyutta FV panel bağlanabilmektedir. Sistem için en ekonomik panel boyutu denenerek bulunacaktır. Seçilen FV boyutunun saatlik olarak ürettiği güç, PVGIS'in 10 yıllık güç verisinden ortalama alarak elde edilen $1 \mathrm{kWp}$ 'lik ortalama üretim verisi boyut ile çarpılarak elde edilmektedir (Örneğin Şekil 1.b).

Tablo 1. InfiniSolar $10 \mathrm{~kW}$ 'llk hibrit evirici (InfiniSolar, 2019) için önerilen panel konfigürasyonu.

\begin{tabular}{|c|c|c|c|c|}
\hline \multirow{11}{*}{\begin{tabular}{|l|} 
Solar Panel \\
Teknik \\
özellikleri. \\
(referans) \\
- 250Wp \\
- Vmp: $36.7 \mathrm{Vdc}$ \\
- Imp: $6.818 \mathrm{~A}$ \\
- Voc: $44 \mathrm{Vdc}$ \\
- Isc: $7.636 \mathrm{~A}$ \\
- Hücre sayısı: 72
\end{tabular}} & SOLAR GİRİŞ 1 & SOLAR GİRİŞ 2 & \multirow{3}{*}{$\begin{array}{c}\begin{array}{c}\text { Panel } \\
\text { Adeti }\end{array} \\
11 \text { adet }\end{array}$} & \multirow{3}{*}{\begin{tabular}{|c|}
$\begin{array}{c}\text { Toplam } \\
\text { Giriş Gücü }\end{array}$ \\
$2750 \mathrm{~W}$
\end{tabular}} \\
\hline & \multicolumn{2}{|c|}{$\begin{array}{l}\text { (Min seri bağlı panel sayısı: } 11 \text { adet; } \\
\text { Max seri bağlı panel sayısı: } 18 \text { adet) } \\
\end{array}$} & & \\
\hline & 11 adet seri & $x$ & & \\
\hline & $x$ & 11 adet seri & 11 adet & $2750 W$ \\
\hline & 11 adet seri & 11 adet seri & 22 adet & $5500 \mathrm{~W}$ \\
\hline & $\begin{array}{c}11 \text { adet seri, } \\
2 \text { paralel }\end{array}$ & $x$ & 22 adet & $5500 \mathrm{~W}$ \\
\hline & $x$ & $\begin{array}{l}11 \text { adet seri, } \\
2 \text { paralel }\end{array}$ & 22 adet & $5500 \mathrm{~W}$ \\
\hline & 18 adet seri & 18 adet seri & 36 adet & $9000 \mathrm{~W}$ \\
\hline & $\begin{array}{l}14 \text { adet seri, } \\
2 \text { paralel }\end{array}$ & 14 adet seri & 42 adet & $10500 \mathrm{~W}$ \\
\hline & $\begin{array}{l}18 \text { adet seri, } \\
2 \text { paralel }\end{array}$ & 18 adet seri & 54 adet & $13500 \mathrm{~W}$ \\
\hline & $\begin{array}{l}15 \text { adet seri, } \\
2 \text { paralel }\end{array}$ & $\begin{array}{l}15 \text { adet serial, } \\
2 \text { paralel }\end{array}$ & 60 adet & $15000 \mathrm{~W}$ \\
\hline
\end{tabular}

\subsection{Talep Altsisteminin Modellenmesi}

EA'lardan gelen güç talebini oluşturan üç tane rassal bileşen: i) Talebin günün hangi zamanında geldiği (geliş zamanı), ii) EA'nın şarj istasyonunda ne kadar kalacağı, iii) EA bataryasının istasyona geldiğindeki doluluk oranı olarak belirlenmiştir. Ele aldığımız sistem bir AVM içerisinde olduğu için, araç sahiplerinin asıl amacının AVM'de vakit geçirmek olduğu, dolayısıyla talep miktarını AVM'de geçirdikleri sürenin belirlediği kabul edilmiştir. Eğer bu şarj istasyonu AVM dişında bir lokasyon, örneğin ofis otoparkındaki EA şarj istasyonu olsaydı, talep bileşenlerinin farklı şekilde ele alınması gerekirdi.

b)

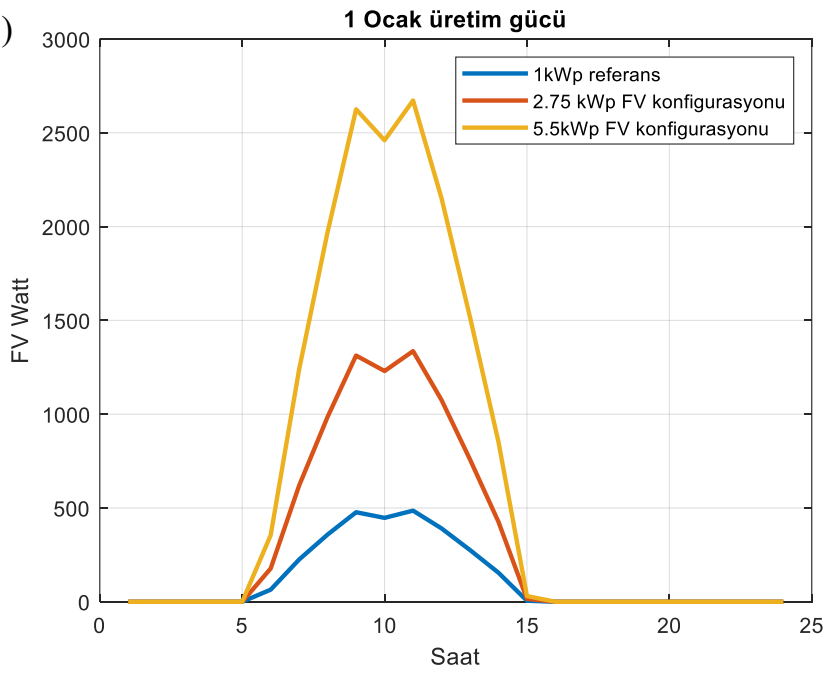

Şekil 1. a)1 kWp'lik kurulum için saatlik 1 yıllık ortalama üretim verisi. b) Farklı FV boyutların güç üretiminin 1 kWp'lik ortalama üretim verisinden elde ediliși. 


\subsubsection{Dünyadaki EA Sayısının Tahmini}

EA'ların sayılarının giderek artması beklenmektedir (IEA, 2018). Dünyadaki EA sayısının nasıl değişeceği ile ilgili ilgili iki tane farklı senaryo konuşulmaktadır: 1) Yeni Politikalar senaryosu, 2)EV30@30 senaryosu.

Yeni Politikalar Senaryosu, Uluslararası Enerji Ajansı'nın Dünya Enerji Görünümü'nün merkezi senaryosudur (IEA, 2018). Senaryo, dünyadaki hükümetlerin daha önce uygulamaya koydukları politikaları ve önlemleri, ayrıca resmi hedeflerde veya planlarda ifade edilen politikaların olası etkilerini içermektedir. EV30@30 senaryosunda ise, temiz enerji ile ilgili uluslararası kuruluşun EA girişimi içerinde yer alan ülkeler tarafindan taahhüt edilen hedef; kişisel otomobiller, otobüsler ve kamyonlar için en az \%30'luk kısmın EA olması konusunda bir pazar payı öngörmektedir. EA sayısının, Şekil 2.a ve 2.b'de gösterilen yeni politikalar ve EV30@30 senaryolarına göre düzenli bir şekilde artacağı öngörülmektedir (IEA, 2018).

$\mathrm{Bu}$ iki senaryoya göre, EA sayısındaki artı̧̧ model içerisine entegre edebilmek amacıyla, Denklem (1) ve (2) de gösterildiği üzere iki fonksiyon MATLAB'in fonksiyon yaklaştırma araçları kullanılarak türetilmiştir (Şekil 2.c,d):

$$
\begin{aligned}
& E A_{E V 30 @ 30}^{\text {Dünya }}(t)=0,01931 t^{2}+446,8 t+5,6 * 10^{6} \\
& E A_{\text {yenipolitikalar }}^{\text {Dünya }}(t)=0,01038 t^{2}+290,4 t+5,6 * 10^{6} \\
& t \in\{0,1,2, \ldots, 219144\}
\end{aligned}
$$

Denklem (3)'te $t=0$ değeri 01.01.2019 tarihinde saat 00:00'a , $t=1$ değeri 01.01.2019 tarihinde saat 01:00'a karş1lık

a)

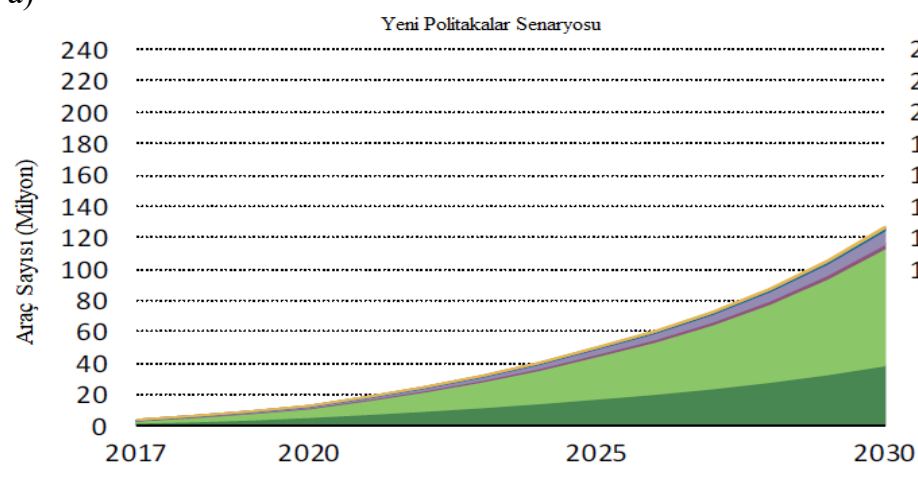

c)

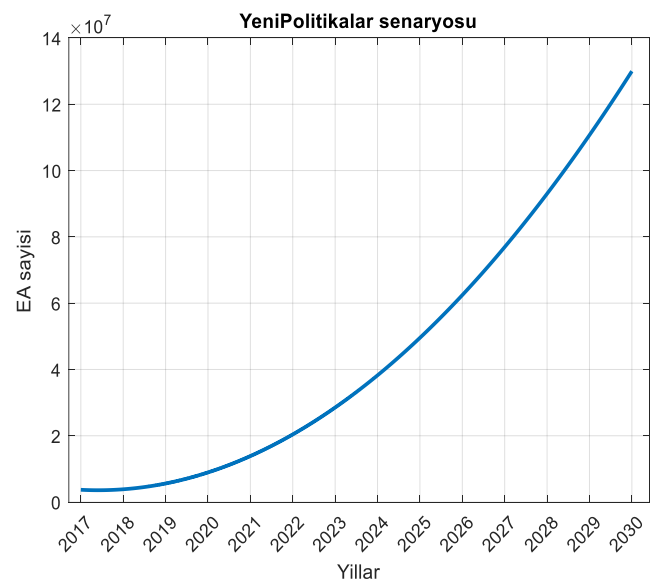

b)

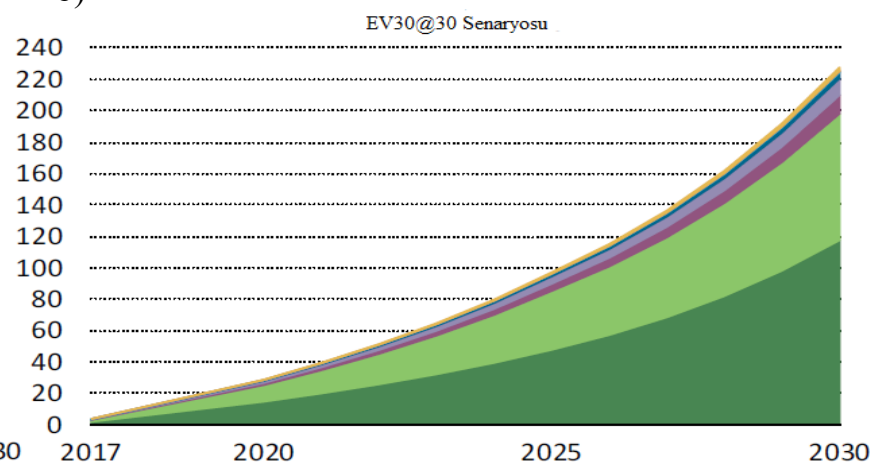

d)

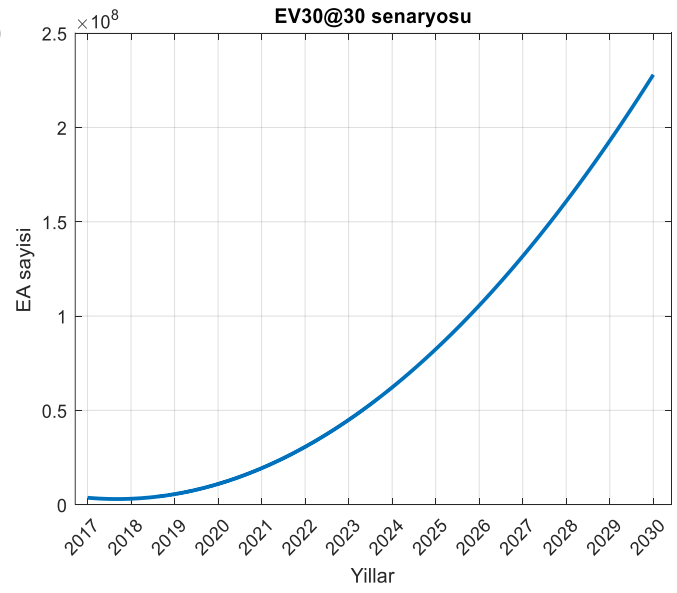

Şekil 2. Elektrikli araç sayısı senaryoları (International Energy Agency, 2018) ve benzetimleri. a) Yeni Politikalar Senaryosu, b) EV30@30 Senaryosu, c) Yeni Politikalar Senaryosu benzetim, d) EV30@30 Senaryosu benzetim. 
a)

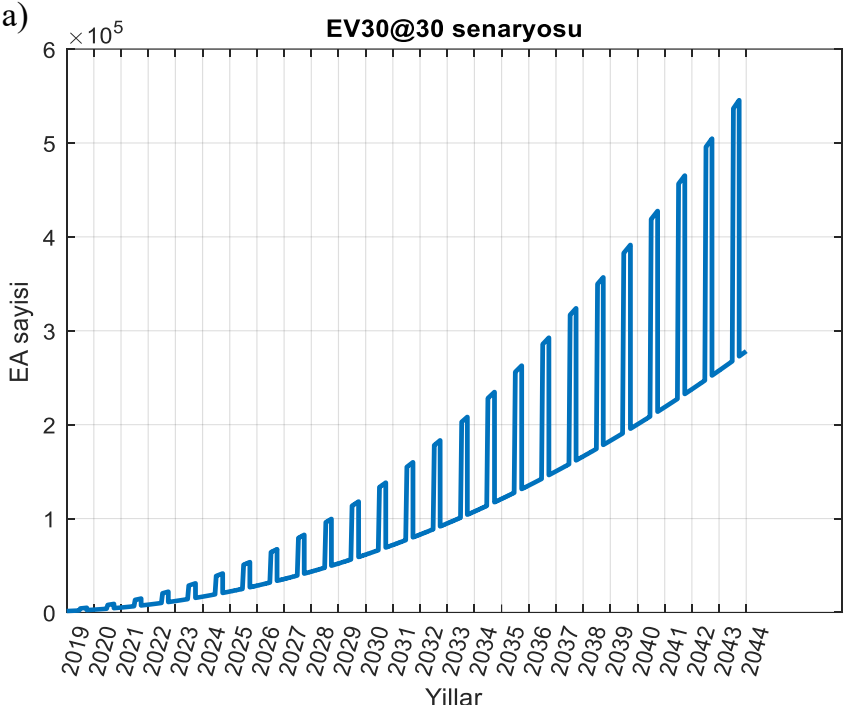

b)

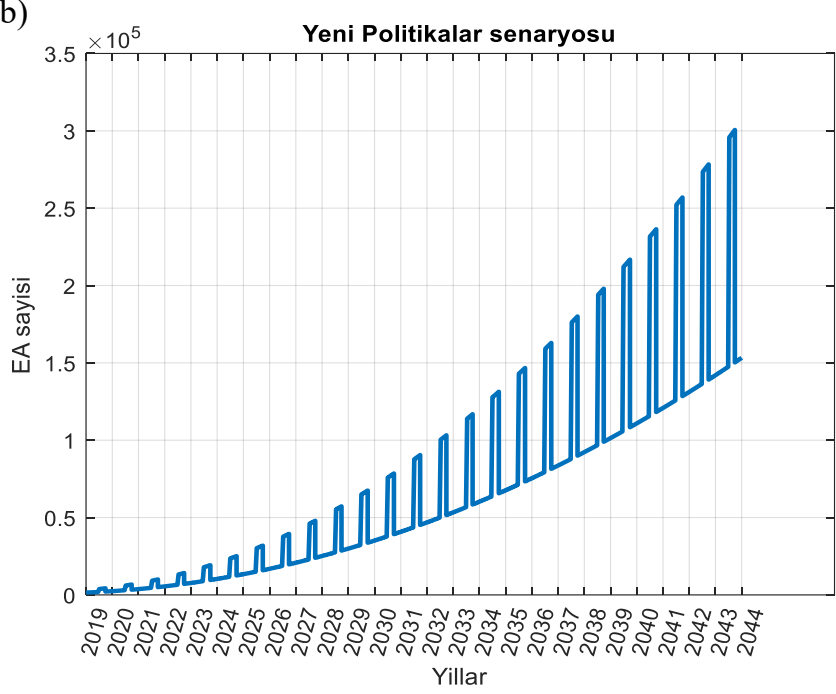

Şekil 3. Senaryo durumlarına göre İzmir'de 2044 yılına kadar tahminî elektrikli araç sayısı. a) EV30@30 senaryosu. b) Yeni Politikalar Senaryosu.

\subsubsection{EA'ların AVM'ye Geliş Zamanlarının Modellenmesi}

Literatürdeki çalışmalarda, temel yaklaşım EA'ların gelme sıklığının, sabit biçim parametresi $(\lambda)$ değerine sahip bir Poisson dağılımı veya saatlik olarak biçim parametresi değeri artan Poisson dağılımı ile modellenmesi üzerine olmuştur (Chrysanidis et al. 2019). Biçim parametresi sabit Poisson dağ 1 lımı, genelde teorik kapalı çözüm bulmak için; saatlik değişen parametre ise, daha gerçekçi bir benzetim modeli elde etmek için kullanılmaktadır. $\mathrm{Bu}$ çalışmada ise, gerçeği olabildiğince yansıtmak amacıyla yaz ve kış sezonlarındaki her gün ve her saat için ayrı olmak üzere geliş sıklığ belirlenmiştir.

Sistem bir AVM düşünülerek kurulduğu için, araçların geliş süreleri bu ortama uygun şekilde belirlenmelidir. Kişilerin AVM ihtiyaçları günlük ve saatlik olarak hem ihtiyaca göre hem de kişilerin çalışma saatlerine göre değişmektedir. Örneğin, hafta sonu ve iş çıkışı saatlerinde yoğunluk daha fazla olabilmektedir. Yani, EA'ların gelme sıklığı, haftanın gününe ve saatine bağlıdır. Ayrıca, EA'ların gelme sıklığını en çok etkileyen diğer faktör ise, EA'ların yaygınlı̆̆ıdır. Dolayısıyla, rassal bir benzetim modeli oluştururken, günü saat saat ele almak ile birlikte, EA'ların toplam araç popülasyonu içindeki oranını da dikkate almak gereklidir.

AVM'ye gelen araçların zamanları ile ilgili çok kısıtlı bir veri bulunmaktadır. İzmir'de EA sayısının az olması nedeniyle bunu belirlemek ancak bazı kabullerle mümkündür. Bu amaçla Google Haritalar (Google, 2019) tarafından AVM'nin her gün için saat saat verilen popülerlik zaman indeks grafiğinden faydalanılmış ve Şekil 4.a'da gösterilmiştir. Her gün için saat bazında AVM'ye EA gelme sıklığının, bu profile benzediği kabul edilmiştir.

Şekil 4.b'de ise MATLAB ortamında tanımlanmış parçalıtanımlı doğrusal fonksiyonun çubuk gösterimi verilmiştir. Ancak bu profil gösteriminde araç veya kişi sayısı gibi sayısal bir bilgi mevcut değildir. Örneğin, akşamüzeri gelen araç sayılarının sabah ve öğlene göre fazla olduğu popülarite profilinden anlaşılabiliyor olmasına rağmen, araçların kaç tane olduğu bilgisi bulunmamaktadır. Yine de bu popülarite profili şu şekilde benzetim modeline dönüştürülebilmiştir: $\lambda_{g, s}^{E A}(t)$ rassal parametresi, bir aracın güne ve saate bağlı olarak AVM'ye gelme sıklığı olarak tanımlanmış ve popülarite profillerine uygun bir fonksiyon olarak kabul edilmiştir. $\lambda_{g, s}^{E A}(t)$ 'nin şehirdeki EA sayısı (yani $E A_{\text {Senaryo }}^{\mathrm{i} z \text { mir }}(t)$ ) ile çarpılması durumunda, AVM'ye belli bir gün ve günün belli bir saatinde EA gelme sıklı̆̆ bulunabilir. $\lambda_{g, s}^{E A}(t)$ bir profil fonksiyonu olduğu için, gerçek sayısal değerleri yansıtacak şekilde ölçeklenmesi gerekmektedir. Bu ölçek değeri $q$ olarak tanımlanmıştır. Dolayısıyla, sözü geçen AVM'ye EA gelme siklığı:

$$
\lambda_{A V M}(t)=q * \lambda_{g, S}^{E A}(t) * E A_{\text {senaryo }}^{\mathrm{i} z \operatorname{mir}}(t)
$$

ifadesinden hesaplanabilir $\left(E A_{\text {senaryo }}^{\mathrm{I} z m i r}(t)\right.$ EV30@30 veya Yeni Politikalar senaryosunu ifade etmektedir).

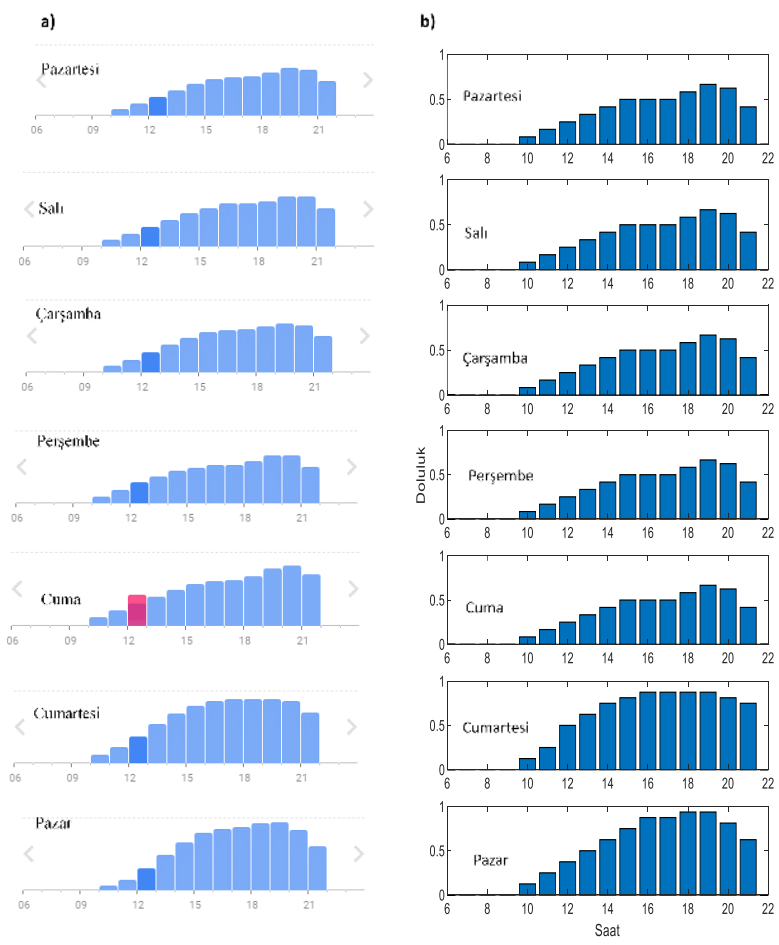

Şekil 4. Alışveriş merkezlerinin saatlik insan popülaritesi. a)

Google'dan alınan veriler. b) MATLAB'ta parçalı tanımlı doğrusal fonksiyonun çubuk gösterimi. Parçalı tanımlı doğrusal 
fonksiyonda, fonksiyonun iki tam saat arasındaki değeri, doğrusal olarak değerlendirilmiştir.

Denklem (5)'teki gibi tanımlanan $\lambda_{A V M}(t)$ parametresine sahip bir Poisson prosesinden rassal geliş zamanları türetildiğinde, AVM'ye gelen EA'ların geliş zamanları bulunmuş olacaktır. Ancak, bu türetim sabit biçim parametresine sahip (homojen) bir Poisson dağılımdan yapılan türetime göre farklıdır. Bunun için, homojen olmayan Poisson dağılımından geliş zamanı türetimi gereklidir. Bu türetim ile ilgili aşağıda gösterilen sözdekod (Algoritma-1) kullanılmıştır.

Algoritma-1. Homojen olmayan Poisson dă̆ılımından geliş zamanı türetimi

$S_{i} \epsilon(0, T)$ zaman aralığında olmak üzere:

1) $t=0, n=0, \lambda=\max _{t \in[0, T]} \lambda_{A V M}(t)$;

2) $t=t-\frac{\ln (\text { Uni }(0,1))}{\lambda}$, if $t>T$

3) if $\operatorname{Uni}(0,1) \leq \frac{\lambda_{A V M}(t)}{\lambda}$, then $n=n+1, S_{n}=t$

4) 2.adıma git

Çıktılar: $n(0, \mathrm{~T})$ zaman aralığında gerçekleşen olay sayıs1, $S_{1}, \ldots S_{n}$ olay zamanları.

Denklem 5'deki $\lambda_{A V M}(t)$ ifadesindeki $q$ ölçek değerinin bulunması için gerçek veriye ihtiyaç duyulmaktadır. İzmir'deki EA'lar ile ilgili internet kaynaklarındaki kısıtlı veri nedeniyle Eşarj firmasından bilgi alınmış ve 12 eşarj istasyonundan Şubat 2019 ayı içerisinde toplamda $700 \mathrm{kWh}$ enerji çekildiği öğrenilmiştir. Ortalama tek bir eşarj istasyonundan $700 / 12 \mathrm{kWh}$, yani yaklaşık $58 \mathrm{kWh}$, enerji çekilmiştir. Bu bağlamda, Şubat 2019 ayı için Algoritma-1 koşturulmuş ve bir şarj istasyonundan $58 \mathrm{kWh}$ civarında enerji talebi oluşturacak şekilde, denemeyanılma yoluyla $q$ değeri $1,1 * 10^{-5}$ olarak bulunmuştur. Burada, AVM'ye konulan bir şarj istasyonunun da diğer şarj istasyonları ile aynı şekilde kullanıcı çektiği düşünülmüştür. Ancak, AVM'ye konulan şarj istasyonlarının normalden daha fazla kullanıcı çekeceği de yadsınamaz bir gerçektir. Dolayısıyla burada yapılan çalışmayı, elde edilebilecek kâr değerinin asgari seviyesi olarak yorumlamak daha doğrudur.

\subsubsection{Gelen EA'ların AVM'de Kalış Süreleri}

Gelen EA'ların şarj istasyonunda kalış süreleri AVM'lerde kişilerin geçirdiği zaman ile belirlenebilir. Tablo 2, AVM'ye gelen kişilerin büyük bir çoğunluğunun 1-3 saat arası vakit geçirdiğini göstermektedir (Konyalıoğlu, 2014). Bu bilgiyi benzetim çalışmalarına entegre edebilmek için, Tablo 2'deki "Yüzde" bilgisini içeren sütun ayrık olasılık dağılımı olarak kabul edilip, gelen her bir EA'nın ne kadar süre kalacağı bu dağılımdan Monte Carlo yöntemiyle üretilmiştir. Monte Carlo ile üretilen "AVM'de geçirilen sürelerin" yüzde olarak çubuk grafiği Şekil 5'te verilmiştir. Tablo 2'deki "Yüzde" sütunu ile Şekil 5 birbiri ile uyumludur.
Tablo 2. Alışveriş merkezinde geçirilen sürelerin dağılımı (Konyalıoğlu, 2014).

\begin{tabular}{|c|c|c|}
\hline Geçirilen Süre & Frekans & Yüzde \\
\hline 1 saatten az & 141 & $\% 27$ \\
\hline $1-3$ saat & 286 & $\% 55$ \\
\hline 3-4 saat & 57 & $\% 11$ \\
\hline Bütün gün & 5 & $\% 1$ \\
\hline Zamanı önemli & 31 & $\% 6$ \\
\hline değil & 520 & $\% 100$ \\
\hline
\end{tabular}

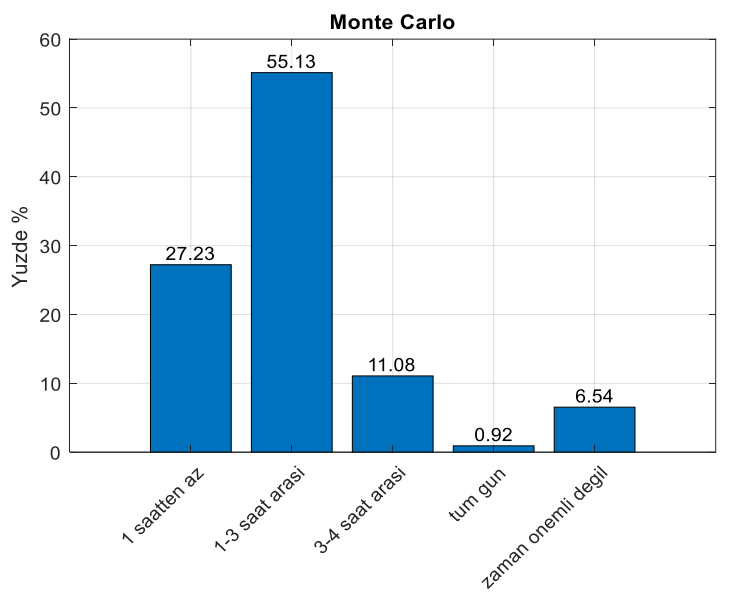

Şekil 5. Aracın alışveriş merkezindeki süresinin Monte Carlo simülasyonu.

\subsubsection{Gelen EA'ların Batarya Şarj Durumunun Benzetimi}

Gelen araçların zamanları rassal olduğu gibi, Şarj Durumu (State of Charge -SOC) dağılımları da rassaldır ve özellikle de günün saatine göre değişmektedir. Bu konuda Wang ve diğerlerinin (2019) yaptığı çalışma baz alınmıştır. Bu çalışmaya göre bir tam gün içerisinde saat 07:00'den gece 00:00'a kadar EA'ların yaklaşık olarak \%35'i batarya kapasitelerinin \%010'unu, \%28'i \%10-20'sini, \%12'si \%20-30'unu, \%19'u \%3070'ini, \%3'ü \%70-100'ünü, \%3'ü ise \%100 veya daha fazlasını kullanmaktadır. Bu yüzdelik bilgiyi ayrık bir dağılım olarak kabul edip, gelen EA'ların gün sonunda tüketmiş olduğu enerji, batarya yüzdelik şarj durumu cinsinden Monte Carlo benzetimi ile bulunmuştur. Şekil 6'da Monte Carlo benzetiminin sonuçları görülmektedir. EA'nın AVM'ye geldiği andaki batarya şarj durumu ise, geliş zamanlarına oranlanarak bulunmuştur. Wang ve diğerlerinin (2019) çalışmasında saat 07:00'den gece 00:00'a kadar 17 saatlik bir süredeki enerji kullanımını vermektedir. Ele aldığımız AVM ise saat 10:00 ile 22:00 arası açıktır. Basit bir orantı ile, gün sonunda $\%$ X SOC harcaması gereken bir aracın AVM'ye geldiği anda ne kadar SOC'si olduğu aşağıdaki Denklem 6 'da olduğu gibi hesaplanmıştır. 


$$
\begin{array}{r}
\operatorname{SOC}\left(t_{\text {geliş}}\right)=\% X * \frac{\left(t_{\text {geliş }}-10+3\right)}{17} \\
10: 00<t_{\text {geliş }}<22: 00
\end{array}
$$

$\operatorname{SOC}\left(t_{\text {geliş̧ }}\right)$, gün sonunda $\% \mathrm{X}$ SOC tüketmesi beklenen bir aracın, AVM'ye geldiği andaki ( $\left.t_{\text {geliş }}\right)$ SOC değerini vermektedir.

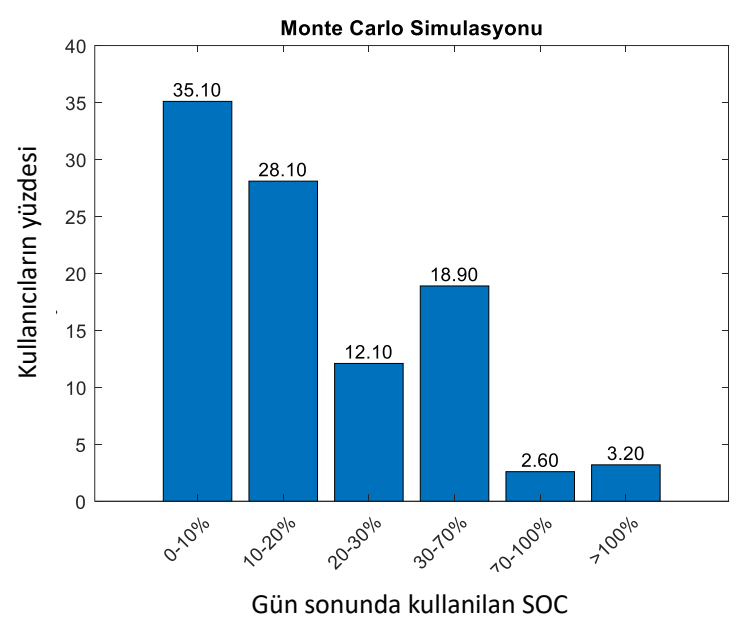

Şekil 6. EA'ların gün sonunda harcadıkları enerjinin SOC cinsinden Monte Carlo simülasyonu.

\subsection{Güç Dengesi Ve Çalışma Modu}

FV destekli ve bataryalı sistemlerde gücün öncelikle nereden sağlanacağı belirlenmelidir. Bu çalışmada, bir yükü beslemek için ilk olarak FV, ikinci olarak akü ve son olarak şebeke gücü kullanıldığı varsayılmıştır. Burada izlediğimiz yol, değerleri belli bir sistem için olmayacak olup, ileride sistem parametrelerinin değişimi durumunda, buradaki metodoloji takip edilerek, sistemin ekonomik analizini yapmaya uygun olacaktır.

Herhangi bir $t$ anında Denklem 7'deki güç dengesi sağlanmak durumundadır:

$$
P_{F V}(t)+P_{\text {Şebeke }}^{\text {Alls }}(t)+P_{\text {Şebeke }}^{\text {Satıs }}(t)+P_{E A}(t)+P_{\text {Bat }}^{\text {Sarj }}(t)+P_{\text {Bat }}^{\text {Desarj }}(t)=0
$$

$\mathrm{Bu}$ formülde, $P_{F V}(\mathrm{t}), t$ anında üretilen $\mathrm{FV}$ gücüdür ve $P_{F V}(t) \geq 0$ ve $P_{E A}(t)$, t anında EA'nın talep ettiği güçtür ve $P_{E A} \leq 0$ eşitsizliği sağlanmak durumundadır.

$$
\begin{gathered}
P_{\text {Șebeke }}^{\text {Alls }} \text { ve } P_{\text {Şebeke }}^{\text {Satıs }} \text { Denklem 8'i sağlamalıdır: } \\
P_{\text {Şebeke }}^{\text {Alıs }} * P_{\text {Şebeke }}^{\text {Satıs }}=0 \\
P_{\text {Şebeke }}^{\text {Alıs }} \leq 0 \\
P_{\text {Șebeke }}^{\text {Satıs }} \geq 0
\end{gathered}
$$

$P_{\text {Şebeke }}^{\text {Alls }}$ ve $P_{\text {Şebeke }}^{\text {Satıs }}$ değişkenleri, pozitif veya negatif değer alabilen tek bir değişkene $P_{\text {Şebeke }}^{\text {Alış/Satıs }}$ indirgenebilir. $P_{\text {Şebeke }}^{\text {Alıs } / \text { Satıs }}$ negatif olduğunda Satış, pozitif olduğunda ise Alış işlemi gerçekleşmiş olur.

Aynı şekilde batarya Denklem 9'u sağlamalı ve aynı anda şarj ve deşarj edilememeli:

$$
\begin{gathered}
P_{\text {Bat }}^{\text {Sarj }} * P_{\text {Bat }}^{\text {Deșarj }}=0 \\
P_{\text {Bat }}^{\text {Sarj }} \leq 0
\end{gathered}
$$

$$
P_{\text {Bat }}^{\text {Deşarj }} \geq 0
$$

Bataryada güç var iken, şebekeden elektrik alınamaması durumu Denklem 10 ile sağlanmaktadır:

$$
P_{\text {Şebeke }}^{\text {Alıs }} *\left(S O C_{B a t, F V}-\% 20\right)=0
$$

Dikkat edilirse, SCADA veya talep tepki (Demand Response) programları gibi akıllı sistemler, bataryada kullanılabilecek güç var iken de şebekeden elektrik alınmasına izin vermekte ve gün içi değişen elektrik fiyatlarına göre şarj ve deşarj durumlarını takvimleyebilmektedir. Bu çalışmada bu durum incelenmemiştir.

Batarya şarj derinliği \%20 olarak seçilmiştir:

$$
\% 20 \leq S O C_{B a t, F V} \leq \% 100
$$

Bahsettiğimiz güç dengesi kısıtları ve denklemlerine uygun olarak MATLAB/Simulink ortamında bir model oluşturulmuştur. Ocak 2019'un birinci günü için, oluşturduğumuz bu modelin güç dengesi benzetimi Şekil 7'de gösterilmiştir. Şekil 7'de alttaki grafik FV sistemindeki bataryanın $\left(S O C_{B a t, F V}\right)$ SOC durumunu, üstteki grafik ise sistem bileşenlerinin güçlerini göstermektedir. Şekil 7.a'da siyah kutu içine alınmış alana dikkat edilirse, FV'nin ürettiği ve EA'ya aktarıldıktan sonra geriye kalan net güç, yani $\left(P_{F V}-P_{E A}\right), S O C_{B a t, F V}$ 'i \%20'den \%100'e getirmiştir. $S O C_{B a t, F V}$ $\% 100$ oluncaya kadar $P_{\text {alış/satış }}$ sifırdır. Ancak, $S O C_{\text {bat,FV }} \% 100$ olduktan sonra $\left(P_{F V}-P_{E A}\right)$ kadar güç şebekeye satılmıştır. Şekil 7.b'de siyah kutu içine alınmış alana baktığımızda ise, bir EA'nın sistemden güç talep ettiği $\left(P_{F V}\right)$ ile $\left(P_{F V}-P_{E A}\right)$ grafiğinin farklı olduğundan anlaşılmaktadır (Şekil 7.a'da $P_{F V}$ ile $\left(P_{F V}-P_{E A}\right)$ üst üste geldiği için kırmızı çizgi, yani $\left(P_{F V}\right)$, görünmemektedir). Önce $\left(P_{F V}-P_{E A}\right)$ pozitif durumda iken EA'y1 şarj etmekte, negatif duruma geçtiğinde ise $S O C_{b a t, F V}$ kullanılmakta ve $S O C_{B a t, F V}$ de bittiğinde gerekli güç şebekeden sağlanmaktadır.

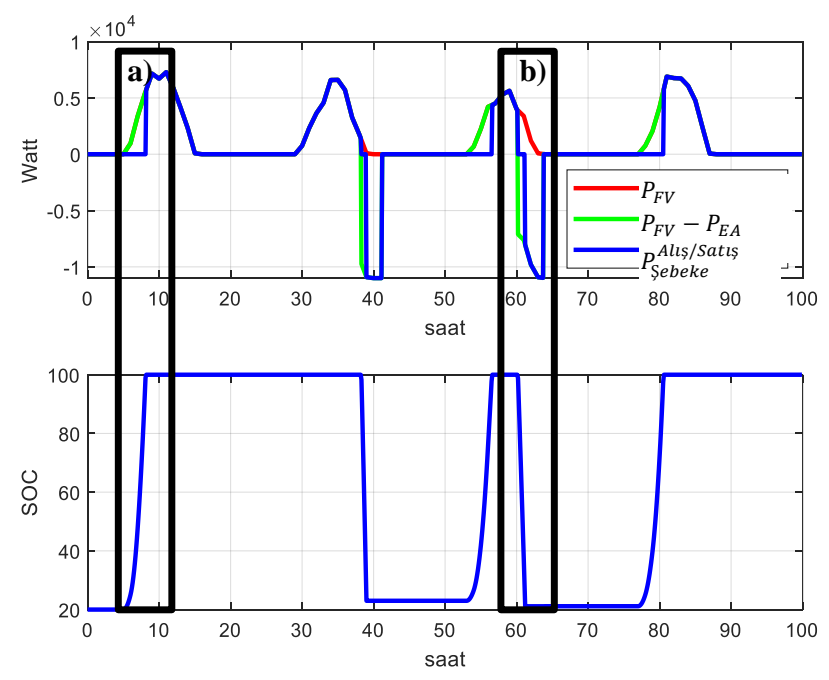

Şekil 7. Güç dengesi simülasyonu.

Özetlemek gerekirse, burada kurgulanmış olan sistem, EA olmadığı durumda $\mathrm{FV}$ 'den üretilen güç ile $S O C_{b a t, F V}$ 'nin dolmasını sağlar. $S O C_{b a t, F V}$ dolduktan sonra ise (halen daha EA yok ise) şebekeye satış gerçekleşir. EA sistemden güç talep ederse, öncelikle FV güç kullanılır. FV gücün yetersiz kaldığg durumda ise, bataryadaki hazırda bekleyen enerji ile destek sağlanır. Bataryada enerji yok ise şebekeden alış gerçekleşir ve EA'nın dolumu kesintisiz bir şekilde tamamlanmış olur. Sonuç olarak bu şekilde kurgulanmış bir sistemde EA şarj için asla geri 
çevrilmemekte ve kesintisiz bir şekilde enerji isteğinin cevaplandığı görülmektedir.

\section{Sonuçlar}

\section{1 Şarj İstasyonu Talep Analizi}

2030 yllına kadar, AVM içerisinde EA şarj talebini karşılayabilecek optimal sayıdaki EA şarj istasyonu sayısı bilinmemektedir. Kurgulanan sistemde, ilk gelen araç 1. istasyona, eğer 1. istasyon dolu ise 2. istasyona gittiği ve bunun bu şekilde N. istasyona kadar devam ettiği kabul edilmiștir. Yapılan analizlerde, 10. istasyona 2044 yılına kadar ihtiyaç görülmemiştir. Her bir istasyona gelen talebin belli bir politika tahmini altında, hangi saatte ve ne kadar olduğu rassal olarak üretilmiștir. Şekil 8'de ve 9'da 2044 yılına kadar, şarj istasyonlarına belli bir anda o ana kadar gelen toplam araç sayısı görülmektedir. Ancak, daha önce bahsedildiği gibi yazarlar olarak AVM içerisindeki şarj istasyonlarına olan talebin şehir içindeki şarj istasyonlarına olan talepten daha fazla olması beklenmektedir. $\mathrm{Bu}$ konuda henüz tatmin edici bir çalışma yapılmamıştır. $\mathrm{Bu}$ durumda ne kadar istasyona ihtiyaç duyulacağının bundan sonraki çalışmalarda birçok faktör ele alınarak incelenmesi gerekmektedir. Burada, AVM'deki EA şarj istasyonlarının şehir içerisindeki şarj istasyonları ile aynı rağbeti gördüğü, fakat AVM içerisinde gün içinde değişen EA popülasyonunun, özellikle de akşam üstü kalabalığının AVM içerisindeki şarj istasyonlarına olan talebi arttırması ve gün

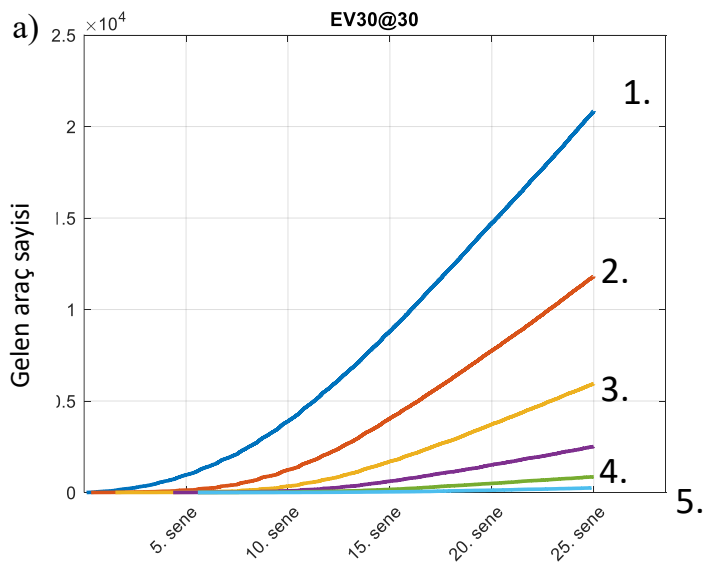

b)

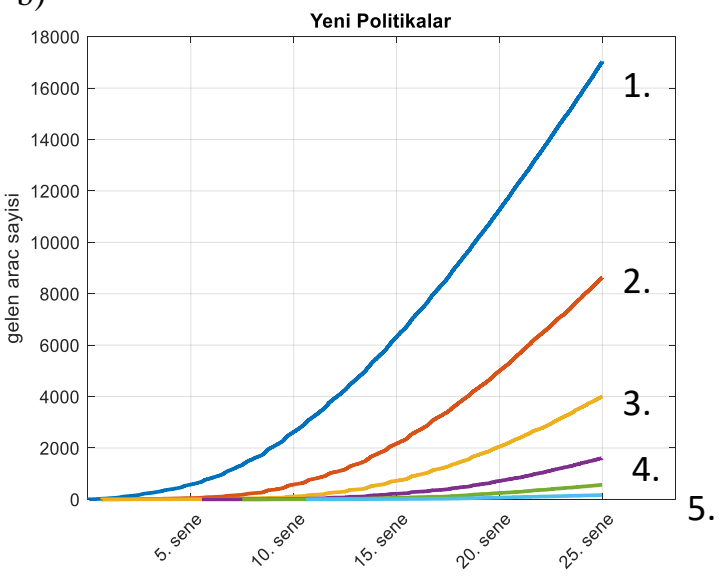

Şekil 8. 2044 yılına kadar 1-5 numaralı şarj istasyonu gelen araç sayısı a)EV30@30 boyunca biriktirilen güneş enerjisinin bu talebin karşılanmasındaki etkisi incelenmiş olacaktır. Özellikle de bu saatlerdeki elektrik talebinin artışının şebeke üzerindeki yükü azaltması da incelenecektir.
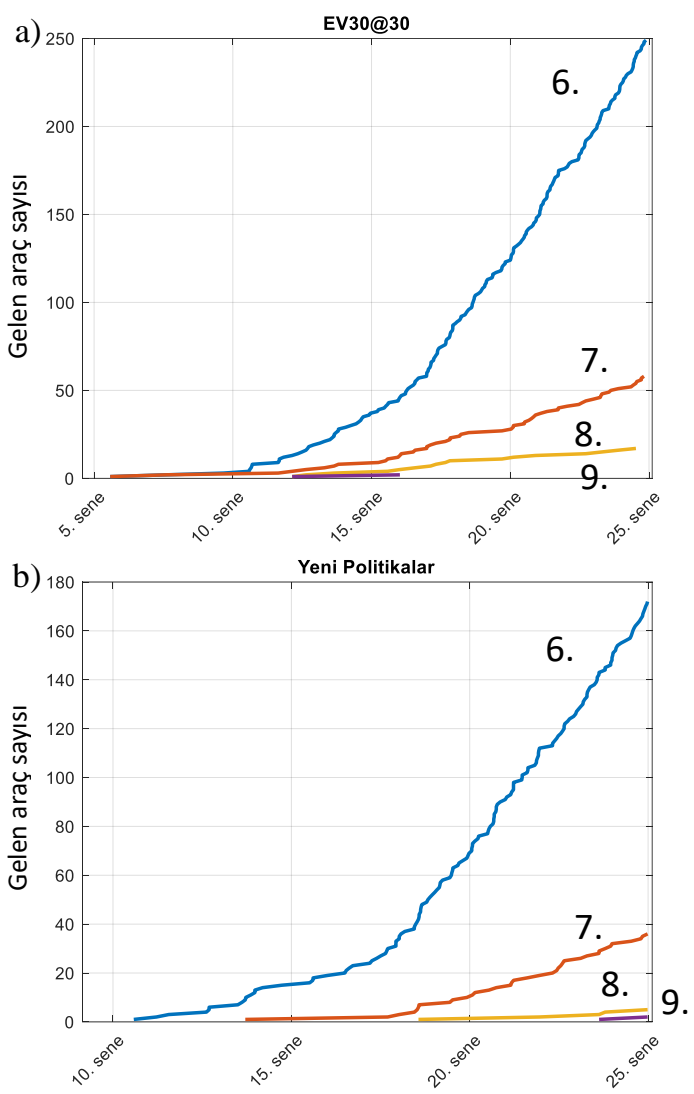

Şekil 9. 2044 yılına kadar 6-9 numaralı şarj istasyonuna gelen araç sayısı a)EV30@30 politikası altında, b) Yeni Politikalar altında.

Sistemdeki rassal değiş̧kenlerin, EA'ların sisteme geliş süreleri, EA'ların sisteme girdiklerindeki batarya SOC değerleri, EA'ların sistemde kalış zamanları ve FV gücü olduğundan daha önce bahsedilmiştir. Bunlara istinaden yukarıdaki grafiklerde görüldüğü üzere, önümüzdeki 25 yıl için iki politika arasında araç gelme sayısında fark olmasına rağmen iki senaryoda da 5 . istasyondan sonra ciddi bir düşüş yaşanmaktadır. 6.-9. istasyonlardaki kazanç tamamen yenilenebilir enerjinin şebekeye sattığ EA şarj istasyonları yatırımlarının maliyet ve geri dönüş süreleri incelenecektir.

\section{2 Şarj İstasyonu Maliyet Analizi}

Her bir araç şarj istasyonu, ayrı ayrı ele alınmıştır. Talep, kurulan modellere göre 2044 yılına kadar oluşturulmuştur. Ancak, FV ve batarya boyutları bilinmemektedir. Bir eviriciye bağlanabilecek olan FV güçleri daha önce Tablo 1'te bahsedildiği gibi, 2750, 5500, 9000, 10500, 13500, 15000 Watt-peak (Wp) olabilmektedir. Benzetim çalıșmaları için düşük, orta ve en yüksek, yani 2750, 9000, ve $15000 \mathrm{Wp}$ değerleri kullanılmıştır. Batarya kapasiteleri de 9600 Wh'nin katları şeklinde olabilmekte ve üst limiti olmamakla birlikte, makul boyutta bir üst limit $5 * 9600 \mathrm{Wh}(48000 \mathrm{Wh})$ olarak belirlenmiştir. Dolayısıyla batarya kapasiteleri 9600, 19200, 28800, 38400, 48000 Wh'dir. Maliyet 
analizi, bu farklı FV ve batarya kapasite boyutlarının tüm bilinmeyen kombinasyonları altında ve FV için watt başına 1,4 TL (Enfsolar, 2019), batarya için ise 0,76 TL (Yiğit, 2019) dikkate alınanarak hesaplamaları yapılmış ve Tablo 3 'te gösterilmiştir.

Belirli bir boyuttaki (boyut $j$-indeksi ile ifade edilmektedir) yenilenebilir enerji kurulduktan sonra, $i$-istasyonundaki kasada herhangi bir $t$ anındaki biriken ciro, Denklem (12)'e göre hesaplanmaktadir:

$$
\begin{gathered}
\text { Ciro }_{i, j}(t)=-F_{\text {Şebeke }}^{\text {Alıs }} \int_{0}^{t} P_{i, j} \text { Alıs }_{\text {Şebeke }}(\tau) d \tau+ \\
F_{\text {Şebeke }}^{\text {Satıs }} * \int_{0}^{t} P_{i, j}^{\text {Satışs }}(\tau) d \tau+F_{E A}^{\text {Satıs }} * \int_{0}^{t} P_{i, j}^{\text {Şebeke }}(\tau) d \tau+ \\
F_{E A}^{\text {Satıs }} * \int_{0}^{t} P_{i, j}^{F V}(\tau) d \tau
\end{gathered}
$$

Sistem için harcanan yenilenebilir enerji maliyeti ise Denklem (13) dikkate alınarak belirlenmiştir.

$$
\begin{gathered}
\text { Maliyet }_{i, j}(t)= \\
F V_{\text {Watt-peak }}(i, j) * 1,4+\text { Bat }_{\text {Watt-saat }}(i, j) * 0,76+ \\
\frac{\text { onoffsayisi }_{650} * \text { Bat }_{\text {Watt-saat }}(i, j) * 0,76}{}
\end{gathered}
$$

Burada, $j$ boyut indeksini, $i$ istasyon numarasını, "onoffsayisi" terimi ise, ilgili istasyondaki bataryanın 25 yılda kaç defa tam şarj ve deşarj olduğu durumu ifade etmektedir. Kullanılan jel akü, 650 yaşam döngüsüne sahip olduğu için, 25 sene içerisindeki ek bakım maliyeti, onoffsayisi teriminin 650 sayısına bölünüp, batarya maliyeti ile çarpılması sonucu bulunmuştur. Batarya ömürü şarj deşarj çekilen akım sıcaklık gibi birçok farklı parametreye bağlıdır. Burada en etkili parametre olan şarj döngüsü ele alınmıştır.

$F_{\text {Alış }}^{\text {Sebeke }}$ şebekeden satın alınan Wh enerji başına fiyat, $F_{\text {Şebeke }}^{\text {Satıs }}$ şebekeye satılan Wh enerji başına fiyat, $F_{\text {Satış }}^{E A}$ EA'ya satılan Wh enerji başına birim fiyat anlamına gelmektedir. $F_{\text {Şebeke }}^{\text {Alls }}=0,73 \mathrm{TL} / \mathrm{kWh}$ (Türkiye Cumhuriyeti Enerji Piyasası Düzenleme Kurumu (EPDK), 2019), $F_{\text {Şebeke }}^{\text {Satıs }}=0,37 \mathrm{TL} / \mathrm{kWh}$ (EPDK, 2019), $F_{E A}^{\text {Satıs }}=1,15 \mathrm{TL} / \mathrm{kWh}$ (Eşarj, 2019) olarak alınmıştır. $i$ istasyonuna ait ve $j$ boyut indeksine sahip FV sistemi, $P_{i, j}$ Alıs $P_{i, j}{ }_{\text {Şebeke }}^{\text {Satıs }}$ üretim fazlası dolayısıyla şebekeye basılan anlık saat bazında gücü, $P_{i, j}^{\text {Sebeke }}$ şebeke tarafindan EA'ya aktarılan anlık saat bazında gücü, $P_{i, j}{ }_{E A}$ ise yenilenebilir enerji (Güneş enerjisi) tarafindan şebekeye aktarılan anlık saat bazında gücü ifade etmektedir. Sistemin çalışma modu gereği $P_{i, j}^{S e b e k e}=P_{i, j}^{\text {Shebeke }}{ }_{E A}^{A l s}$ durumundadır. Herhangi bir anda EA'ya aktarılan anlık toplam güç ise Denklem (14)'teki formül ile hesaplanabilmektedir.

$$
P_{i, j}^{Y E}(\tau)
$$$$
P i, j_{E A}^{\text {Total }}(\tau)=P_{i, j_{E A}}^{\text {Sebeke }}(\tau)+
$$

Sadece yenilenebilir enerji tarafından sağlanan kazanç ise yenilenebilir enerjiden şebekeye satılan enerjiden gelen ciro ile yenilenebilir enerjiden EA'ya satılan enerjiden gelen ciro toplamı olarak

$$
\operatorname{Ciro}_{i, j}^{F V}(t)=F_{\text {Şebeke }}^{\text {Satıs }} * \int_{0}^{t} P_{i, j}^{\text {Satış }} \underset{\text { ebeke }}{\text { Su }}(\tau) d \tau+F_{E A}^{\text {Satış }} *
$$

$\int_{0}^{t} P_{i, j}^{F V}(\tau) d \tau$ denkleminden hesaplanmıştır. $\mathrm{Bu}$, yenilenebilir enerjinin

\begin{tabular}{|c|c|c|c|c|}
\hline $\begin{array}{c}\text { Boyut } \\
\text { İndeksi }\end{array}$ & $\begin{array}{c}\text { FV Boyutu } \\
\text { (Wp) }\end{array}$ & $\begin{array}{c}\text { Batarya } \\
\text { Boyutu } \\
\text { (Wh) }\end{array}$ & $\begin{array}{c}\text { İlk } \\
\text { Yatırım } \\
\text { Maliyeti } \\
\text { (TL) }\end{array}$ & $\begin{array}{c}\text { Ek Maliyet } \\
\text { (Her batarya } \\
\text { değişiminde) } \\
\text { (TL) }\end{array}$ \\
\hline 1 & 0 & 0 & 0 & 0 \\
\hline 2 & 2750 & 0 & 3850 & 0 \\
\hline 3 & 9000 & 0 & 12600 & 0 \\
\hline 4 & 15000 & 0 & 21000 & 0 \\
\hline 5 & 2750 & 9600 & 11146 & 7296 \\
\hline 6 & 9000 & 9600 & 19896 & 7296 \\
\hline 7 & 15000 & 9600 & 28296 & 7296 \\
\hline 8 & 2750 & 19200 & 18442 & 14592 \\
\hline 9 & 9000 & 19200 & 27192 & 14592 \\
\hline 10 & 15000 & 19200 & 35592 & 14592 \\
\hline 11 & 2750 & 28800 & 25738 & 21888 \\
\hline 12 & 9000 & 28800 & 34488 & 21888 \\
\hline 13 & 15000 & 28800 & 42888 & 21888 \\
\hline 14 & 2750 & 38400 & 33034 & 29184 \\
\hline 15 & 9000 & 38400 & 41784 & 29184 \\
\hline 16 & 15000 & 38400 & 50184 & 29184 \\
\hline 17 & 2750 & 48000 & 40330 & 36480 \\
\hline 18 & 9000 & 48000 & 49080 & 36480 \\
\hline 19 & 15000 & 48000 & 57480 & 36480 \\
\hline
\end{tabular}
amortisman süresi hesabında kullanılacaktır. Denkleme bakıldığında, yenilenebilir enerjinin iki alıcısı bulunmaktadır. Bunlardan biri şebeke, diğeri ise EA'dır. EA'ya 1,15 TL/kWh birim fiyattan enerji satışı gerçekleşirken, şebekeye ise 0,37 $\mathrm{TL} / \mathrm{kWh}$ birim fiyattan satış gerçekleştirmektedir.

Tablo 3. Fotovoltaik ve batarya boyutlarının tüm kombinasyonlarl.

\subsubsection{FV Boyutlandırmasının Kazanca Etkisi}

Tablo 3'te verilen tüm FV ve batarya sistemi boyutları için iki farklı EA araç sayısı tahmini olan EV30@30 ve Yeni Politikalar altında, 10 EA şarj istasyonunun 25 sene boyunca simulasyonu yapılmış ve bu belirtilen sene sonunda, her bir farklı 
boyut indeksi $j$ ve farklı istasyon $i$ için $\left(K a ̂ r_{i, j}(t)=\operatorname{Ciro}_{i, j}(t)-\right.$ Maliyet $\left._{i, j}(t)\right)$ analiz edilmiştir.

Maliyet analizinde belirtilen şebekeye alış-satış ve EA'ya satış fiyatı dikkate alınmıştır. Bahsedilen fiyatlarda EA'ya elektrik satmak şebekeye satmaktan daha kârlı olacağı için, bir şarj istasyonuna ne kadar çok EA gelirse kazancı o kadar fazla olacaktır. Bu durumu daha iyi görebilmek için, 1. istasyon tek başına ele alınmıştır. Şekil 10.a'da EV30@30 senaryosu altında yatırım maliyeti düşülmeden 25 sene sonunda kasada biriken ciro,

a)

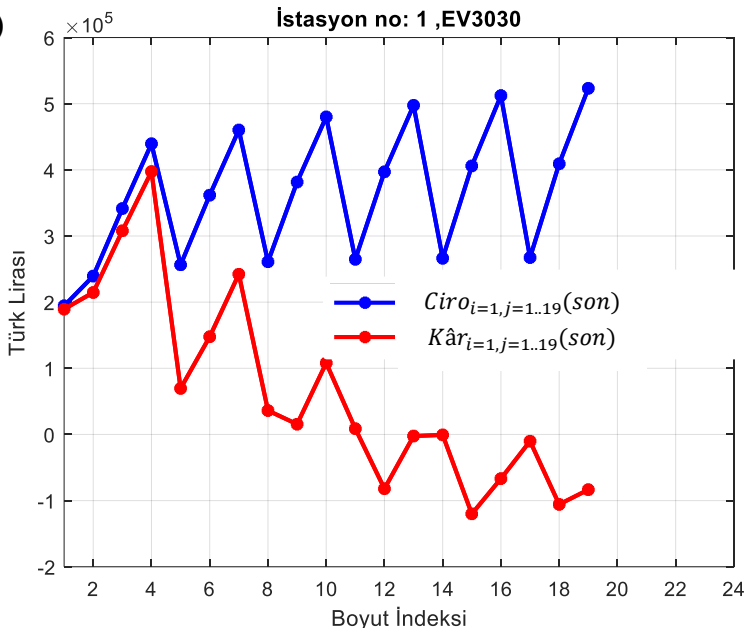

b)

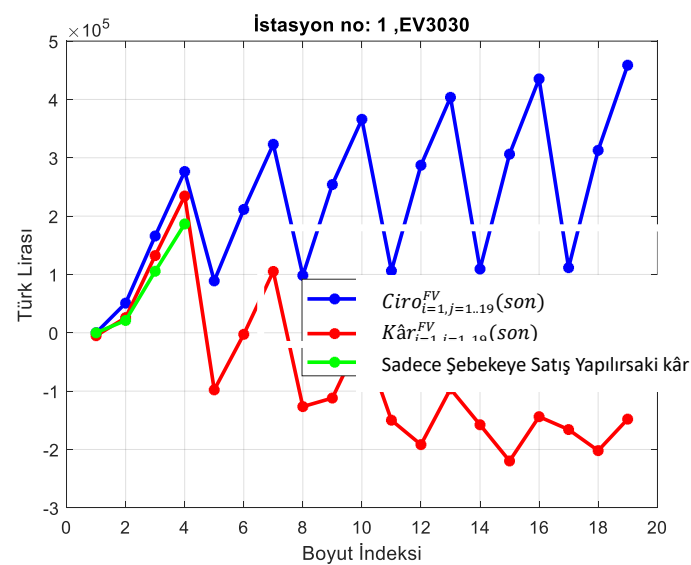

Ciro $_{i=1, j=1 . .19,}$ (son) ve $K$ âr $r_{i=1, j=1 . .19}$ (son), biriken para boyut indeksi $(j) \mathrm{x}$-ekseninde $\mathrm{x}$-ekseninde, Türk Lirası cinsinden kazanç ise y-ekseninde olmak üzere çizilmiştir.

Şekil 10. a)EV30@30 için en yoğun 1. istasyonun toplam kazanc1. b) EV30@30 için en yoğun 1. istasyonun yenilenebilir enerji kazanc1.

Şekil 10.b'de 1. İstasyondan sadece yenilenebilir enerjinin EA elektrik satışına katkısı görselleştirilmiştir. Şekil 10.b'de üretilen yenilenebilir enerji sadece şebekeye satış yapıldığı durumda elde edilecek olan kâr, EA şarj istasyonunun da dâhil olduğu durumdaki kâr ve ciro çizilmiştir. Şekil 10.b'de zigzag çizerek ilerleyen mavi çizginin tepe noktaları farklı batarya kapasitelerine sahip $15 \mathrm{kWp}$ 'lik kurulu güçlere denk gelmektedir. Görüldüğü üzere, indeks 19'a doğru ilerledikçe, bu tepe noktalarının karşılık geldiği değer de büyümektedir. Bunun nedeni, bataryada biriken enerjinin, gün sonunda EA'lara satılabilmesidir. Ancak bu yanıltıııdır. Çünkü yatırım maliyetleri dikkate alındığında, sistem kendini amorti edememektedir. Bunun nedeni, EA'ların bataryaları çok hızlı bir şekilde deşarj etmeleri ve sene içerisindeki şarj ve deşarj sayılarını artırarak, bataryanın ömrünü düşürmeleridir. Bu durumda, yaklaşık olarak her sene batarya maliyeti çıkmaktadır. Aynı durum, Şekil 11'de gösterilen Yeni Politikalar senaryosu altındaki analiz için de geçerlidir. Yeni Politikalar senaryosu, EV30@30 senaryosuna göre daha az EA araç sayısı öngörmektedir. Dolayısıyla, Şekil 11'de 1. İstasyonda daha az kazanç görülmektedir.

a)

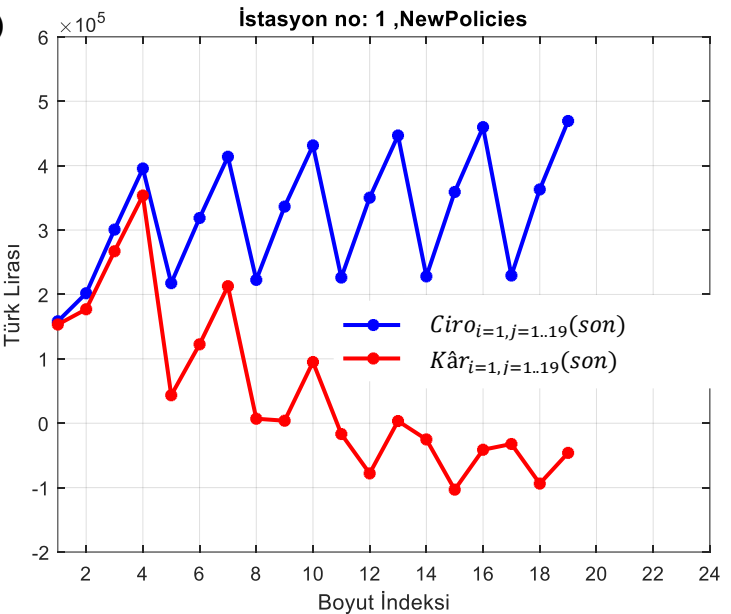

b)

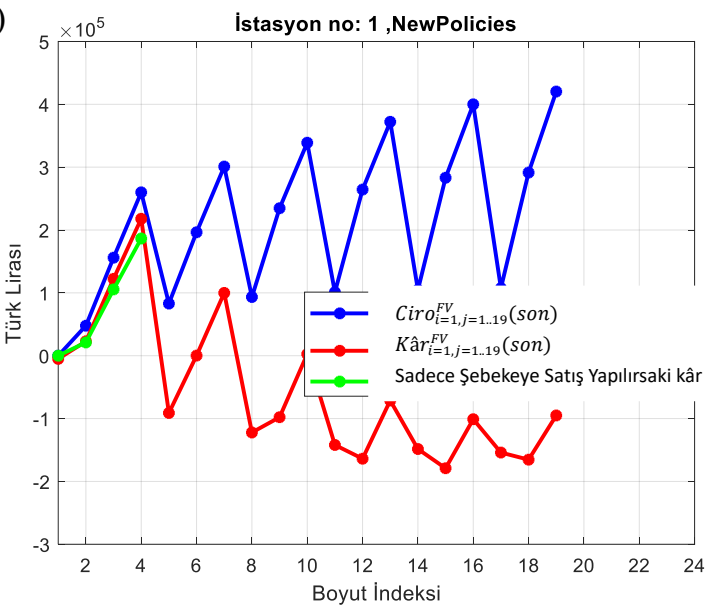

Şekil 11. a) Yeni politikalar (New Policies) için en yoğun 1. istasyonun toplam kazanc1. b) Yeni politikalar için en yoğun 1. İstasyonun yenilenebilir enerji kazanc1.

Farklı istasyonlarda, araç gelme sıklığı farklı olacağından toplam kazanç da farklı olacaktır. 1. istasyon, EA gelme sıklığı en fazla istasyon olup, 10. istasyona doğru siklık giderek azalmaktadır (9. ve 10. istasyonların maliyetleri çok yakın olduğundan, 9. istasyon'a kadar inceleme yapılmıştır). EA'ya elektrik satışı, şebekeye satıştan daha kârlı olduğu için, 1. istasyondan 9. istasyona aynı FV kurulu güç altında, kurulum sonrası kasaya giren para da azalmaktadır (Şekil 12.a). Ancak, yatırım maliyeti düşürüldüğünde, yüksek numaralı istasyonlar avantajlı konuma geçmektedir (Şekil 12.b). Bunun nedeni, az EA sayıları sebebiyle, batarya değişimlerinin düşük veya hiç olmamasıdır. Bu durumda, bataryalı güneş sistemlerinin EA şarj istasyonları için avantajsız ve kötü yatırım olduğu görülmektedir. 
sadece yenilenebilir enerjiden elde edilen kâra yaklaşmaktadır
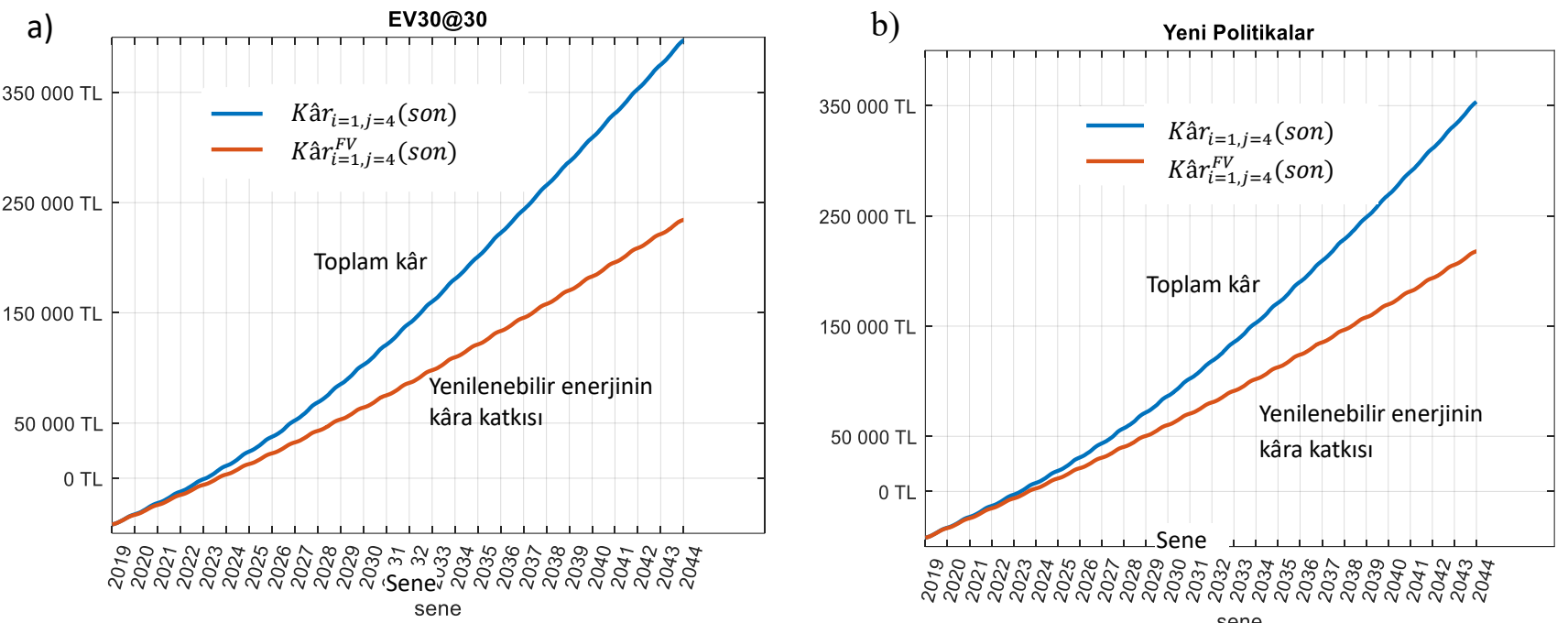

Şekil 13. a)EV30@30 altında 1. istasyon için yenilenebilir enerjinin sistem kazancına etkisi. b) Yeni Politikalar senaryosu altında 1. istasyon için yenilenebilir enerjinin sistem kazancına etkisi.

(Şekil 14)

a)

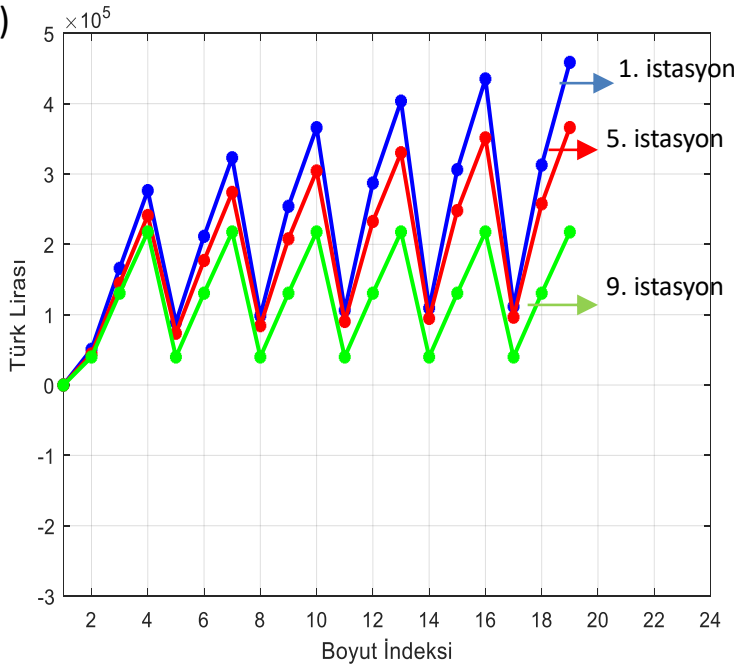

b)

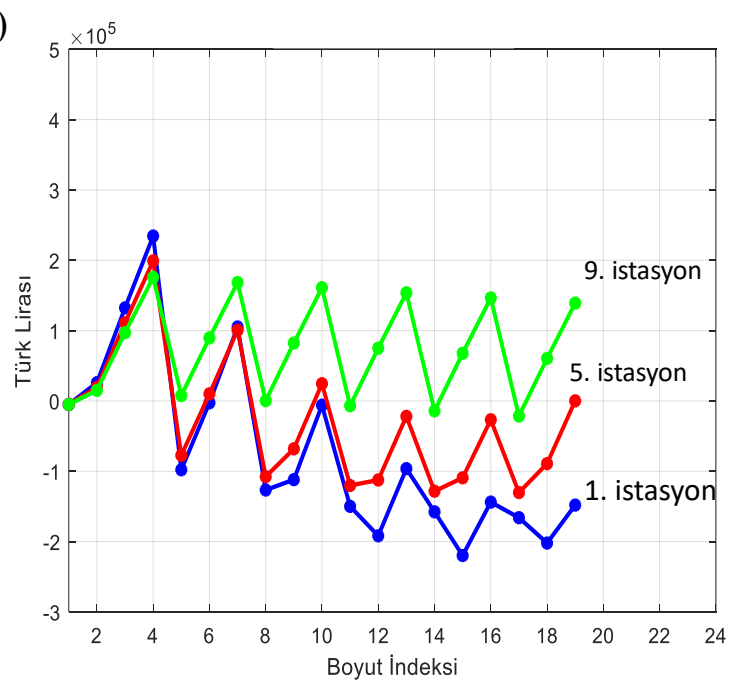

Şekil 12. a)EV30@30 politikası altında 1, 5 ve 9. istasyonlardaki yatırım sonrası 25 sene sonunda kasadaki para.

b) EV30@30 politikası altında 1, 5 ve 9. istasyonlardaki maliyet düşüldükten sonra 25 sene sonunda kasadaki para.

\subsubsection{Yenilenebilir Enerjinin Kazanca Katkısı}

Yenilenebilir enerjinin getirisi, şebekeye elektrik satışından veya EA'ya elektrik satı̧ıından oluşmaktadır. Toplam kâr içerisinde ise, şebekeden alınıp EA'ya satılan elektrik de bulunmaktadır. Yenilenebilir enerjinin kazanc1, batarya olmadan $15 \mathrm{kWp}$ kurulu FV güç için (boyut indeksi $j=4$ ) ve en yoğun olan 1. İstasyon $(i=1)$ için EV30@30 senaryosu altında saat saat bulunmuştur. Toplam kâr ile sadece yenilenebilir enerjinin kârı, maliyetleri düşüldükten sonra hesaplanmış ve Şekil 13.a'da verilmiştir. Görüldüğü üzere, yenilenebilir enerji 1. istasyon ve 15 kWp'lik kurulu güç için, yaklaşık yarı yarıya bir kâr getirisi sağlamaktadır. Yeni Politikalar senaryosu altında ise, toplam kazanç daha az olmaktadır (Şekil 13.b). Şekil 14'te istasyon numaralarına karşılık olarak toplam kâr ve "yenilenebilir enerjinin kâra katkısı" çizilmiş̧ir. Görülmektedir ki şarj istasyonuna gelen EA sayısı düşmeye başladıkça, toplam kâr 


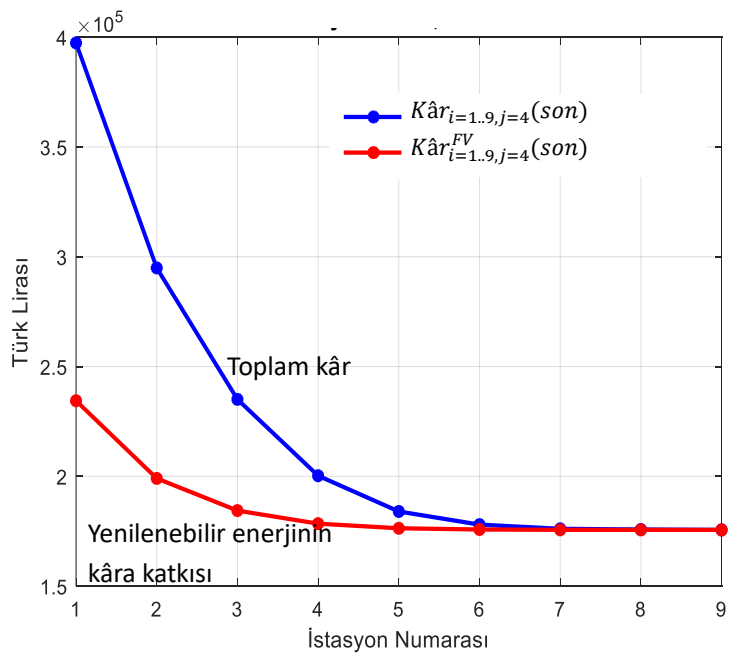

Şekil 14.EV30@30 politikası altında tüm istasyonların 25 sene sonundaki toplam kazancı ve yenilenebilir enerji kazanc1.

Yenilenebilir enerji, EA’ya satışından elde ettiği kazanç ile şebekeye sattığı durumda elde edeceği kazanç daha fazla olacağından, amortisman süresi sadece şebekeye sattığı duruma göre daha az olacaktır (Şekil 15.a). Ancak, 1. istasyon ile diğer istasyonlar arasında büyük bir amortisman fark1 bulunmamaktadır. Bunun nedeni, ilk 10 yılda İzmir için EA sayısının fazla olmayışıdır. Eğer yenilenebilir enerji 2019 değil de 2029 yılında (10.yılda) kurulmuş olsayd1, istasyonların amortisman süreleri arasında daha fazla fark bulunduğu görülmüştür (Şekil 15.b).
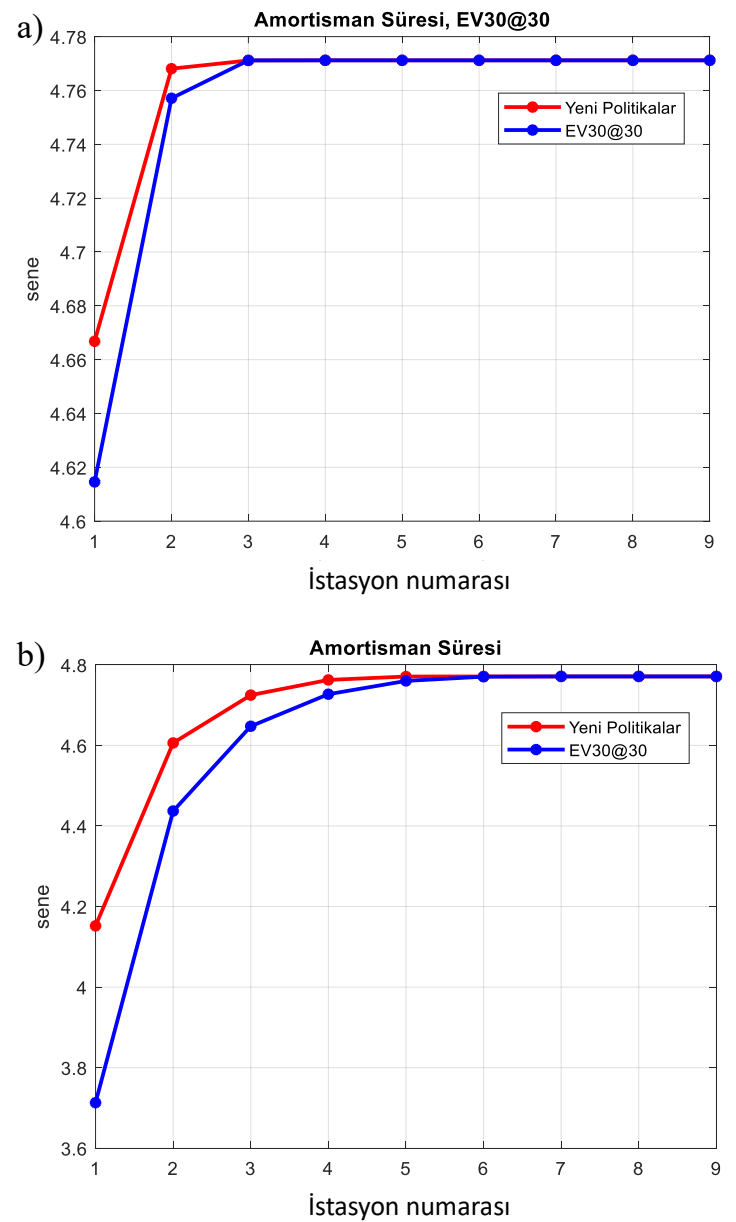

Şekil 15. a) Her bir istasyondaki yenilenebilir enerjinin amortisman süresi. b) Her bir istasyondaki yenilenebilir enerjinin 2029 yılında kurulmuş olduğundaki amortisman süresi.

EA sayısı arttıkça yenilenebilir enerji kullanımının toplam kâr üzerindeki etkisi giderek azalacaktır. Ancak, yine de unutulmamalıdır ki, EA sayısı arttıkça şebekeye binen yük ciddi biçimde artacaktır. Kullanılan yenilenebilir enerjinin kâr dışındaki toplumsal katkısı ise şebeke üzerine binen bu yükün hafifletilmesidir. Şekil 16'da farklı boyutlardaki FV sisteminin, EA'lar tarafindan şebekeye bindirilen yükün 25 yılda ortalama ne kadar düşürüldüğü gösterilmiştir. Yeşil çizgi, FV sistem kurulmasaydı olacak olan toplam güç iken, mavi çizgiler, 2,75 $\mathrm{kWp}, 9 \mathrm{kWp}$ ve $15 \mathrm{kWp}$ kurulu güç durumundaki düşüşü ve kırmızı çizgiler ise, sistem bataryalı olduğu durumdaki düşüşü göstermektedir. Bataryalı güneş enerjisi sisteminin kurulumu, maliyeti amorti edemeyecek derecede yüksek olsa da bu sistemlerin şebekeye bindirilen yükü daha fazla hafifletme eğilimine sahip olduğu görülmüştür.

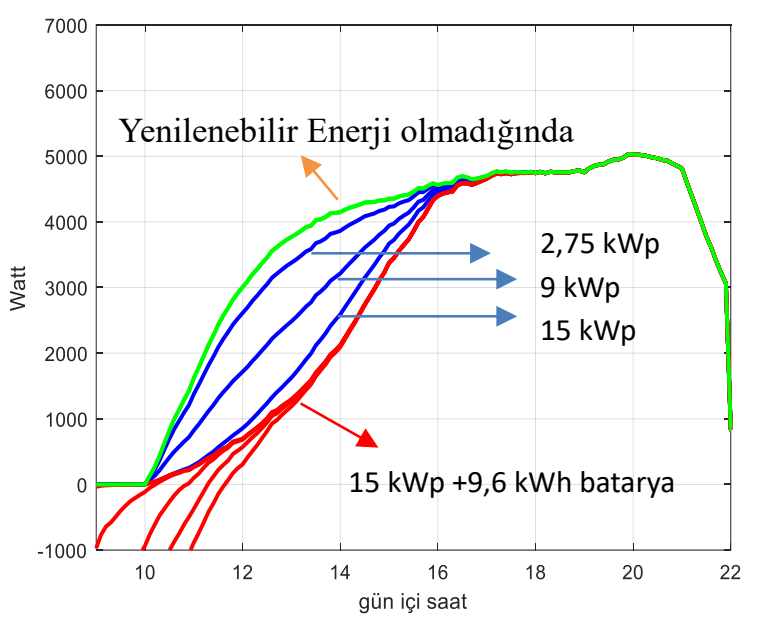

Şekil 16. Yenilenebilir enerji kullanmanın şebeke üzerindeki etkisi.

\section{Sonuç ve Öneriler}

$\mathrm{Bu}$ çalışmada yapılan analizler sonucunda 5. istasyondan sonraki şarj istasyonları, EA'ya enerji satmaktan ziyade, üretilen elektriğin şebekeye satılması sonucu gelir elde ettiği anlaşılmıştır. $\mathrm{Bu}$ sonuçlara göre $\mathrm{FV}$ ve batarya boyutlarının tüm kombinasyonları altında senaryo fark etmeksizin indeks 19'a doğru (FV ve batarya boyutlarının en büyügüu) şarj istasyonu kazancının arttığı ( 500.000 TL) görülmektedir. EA'ya enerji satmak şebekeye satmaktan daha kârlı olduğu için bu durumda en çok araç gelen ve enerji satan 1. istasyon ( 500.000) TL 9. istasyona ( $200.000 \mathrm{TL})$ göre avantajlı durumdadır. Fakat yatırım maliyeti de göz önüne alındığı zaman (bataryaların bakım ve değiştirme vb.) kazanç sağlamadığı görülmüştür. Bunun nedeni, bataryaların belli bir şarj döngüsüne sahip olması ve EA'ların çok güçlü ve sürekli bir şekilde bu yaşam döngüsünü bitirmesi sonucu değişim veya bakım gerektirmesidir. Bu durumda ise, istasyon sayısı arttıkça o istasyona gelen EA sayısı azaldığı için çektikleri güç ve bataryanın şarj döngüsü çok fazla etkilenmemekte ve örneğin 9. istasyon ( 150.000 TL) 1. istasyona göre daha karlı bir duruma geçmektedir. Sadece yenilenebilir enerjiyi şebekeye satar ise kârı ( 200.000 TL) civarı olmaktadır. Güneş enerjisi, 
sistemdeki kazancı iki senaryo içinde yaklaşık yarı yarıya arttırmaktadır. İstasyon EA'ya sattığından daha fazla para kazandığ 1 için 1 . istasyonun amortisman süresinin diğerlerine göre bariz farklı olması beklenmektedir. Fakat istasyonlar arasında büyük bir fark yoktur. Bunun nedeni, hedef ildeki EA sayısının azlığıdır. Araç sayısı arttıkça istasyonlar arasındaki amortisman süresi farkı da artacaktır.

$\mathrm{Bu}$ çalışma ile ilgili olarak dikkat edilmesi gereken konu simülasyon modeli oluştururken birçok parametrenin kestirim ve kabuller altında belirlenmiş olmasıdır. Önümüzdeki yıllarda bu parametrelerin öngörülenden farklı olarak değişimi bu çalışmanın sonuçlarını da etkileyecektir. Bu durumda, yine de bu çalışmada sunulan metodoloji takip edilerek daha kesin neticeler elde edilebilir.

Sonuç olarak; yenilenebilir enerji, şebekeden satın alınan enerjiye göre daha az maliyetli olarak enerji üretebilmektedir. Dolayısıyla, bu üretilen enerjinin EA şarj istasyonunda kullanılması, daha yüksek gelir elde edilmesine olanak sağlamaktadır. EA şarj istasyonlarına bataryalı yenilenebilir enerji sistemlerinin entegre edilmesi durumunda, maliyeti çok artırarak sistemin kendini amorti edemediği görülmüştür. Dolayısıyla, yenilenebilir enerji entegrasyonunun bataryasız olarak gerçekleştirilmesi önerilmektedir. Ancak, şebekenin güvenliği açısından bakıldığında, bataryalı sistemlerin şebekeye binen yükü daha da azalttığ görülmüştür. Bu durumda, bataryalı sistemlere ek teşvik verilerek veya bataryaların daha ucuza mal edilmesinin bir yolu bulunarak maliyetlerin azaltılması ve akıllı şehirler kapsamında şarj istasyonlarının kendi aralarında haberleşerek boş olana araçların yönlendirilmesi ile tek bir hattan sürekli güç çekilmemesi, şebeke güvenliği açısından ileriki yıllarda önem kazanacaktır.

\section{Teşekkür}

Eşarj (İzmir) firmasına, bu çalışma kapsamında verdiği bilgilerden ötürü teşekkür ederiz.

\section{Kaynakça}

Chrysanidis, G., Kosmanos, D., Argyriou, A., \& Maglaras, L. (2019). Stochastic optimization of electric vehicle charging stations. Proceedings-2019 IEEE SmartWorld, Ubiquitous Intelligence and Computing, Advanced and Trusted Computing, Scalable Computing and Communications, Internet of People and Smart City Innovation, SmartWorld/UIC/ATC/SCALCOM/IOP/SCI 2019, 1-7. https://doi.org/10.1109/SmartWorld-UIC-ATC-SCALCOMIOP-SCI.2019.00046

Dong, X., Mu, Y., Xu, X., Jia, H., Wu, J., Yu, X., \& Qi, Y. (2018). A charging pricing strategy of electric vehicle fast charging stations for the voltage control of electricity distribution networks. Applied Energy, 225(92), 857-868. https://doi.org/10.1016/j.apenergy.2018.05.042

EİGM, 2020, Enerji İşleri Genel Müdürlüğü Denge Tabloları. https://www.eigm.gov.tr/File/?path=ROOT\%2f4\%2fDocum ents $\% 2$ fDenge+Tablosu $\% 2$ f2018_Y\%c4\%b11\%c4\%b1_Gen el_Enerji_Denge_Tablosu_R1.xlsx (Erişim Tarihi: $01.07 .2020)$

Enfsolar, Solar Panel Directory, https://www.enfsolar.com/pv/paneldatasheet/crystalline/41609/138754?utm_source=ENF\&utm e-ISSN: 2148-2683 _medium=panel_list\&utm_campaign=enquiry_product_dire ctory\&utm_content $=4777$ (Erişim Tarihi: 30.08 .2019$)$.

Eşarj, https://esarj.com/urunler (Erişim Tarihi: 01.10.2019).

European Commission, Photovoltaic Geographical Information System, https://re.jrc.ec.europa.eu/ (Erişim Tarihi: 08.10.2019).

Jian, L., Zheng, Y., Xiao, X., \& Chan, C. C. (2015). Optimal scheduling for vehicle-to-grid operation with stochastic connection of plug-in electric vehicles to smart grid. Applied Energy, 146, 150-161. https://doi.org/10.1016/j.apenergy.2015.02.030

Jiang, X., Wang, J., Han, Y., \& Zhao, Q. (2017). Coordination Dispatch of Electric Vehicles Charging/Discharging and Renewable Energy Resources Power in Microgrid. Procedia Computer Science, 107(Icict), 157-163. https://doi.org/10.1016/j.procs.2017.03.072

Google Haritalar, https://goo.gl/maps/JcEwvYWXzwBN22XB9 Tarihi:15.11.2019).

InfiniSolar, Hybrid 10kW PV Inverter User Manual, http://www.mppsolar.com/manual/MPI\%2010K\%20HYBRI D\%203-PHASE/MPI\%20HYBRID10KW-manual20180301.pdf (Erişim Tarihi: 01.10.2019).

International Energy Agency, 2018, Global EV Outlook, Organization for Economic Co-operation and Development, France, 139p.

Konyalıoğlu, S. (2014). Tüketicilerin alışveriş merkezi (AVM) tercihlerinde avm yönetiminin önemi.

Liang, H., Liu, Y., Li, F., \& Shen, Y. (2019). Dynamic Economic/Emission Dispatch Including PEVs for Peak Shaving and Valley Filling. IEEE Transactions on Industrial Electronics, 66(4), 2880-2890. https://doi.org/10.1109/TIE.2018.2850030

Liu, L., Kong, F., Liu, X., Peng, Y., \& Wang, Q. (2015). A review on electric vehicles interacting with renewable energy in smart grid. Renewable and Sustainable Energy Reviews, 51, 648-661. https://doi.org/10.1016/j.rser.2015.06.036

Mohammadi Landi, M., Mohammadi, M., \& Rastegar, M. (2018). Simultaneous determination of optimal capacity and charging profile of plug-in electric vehicle parking lots in distribution systems. Energy, 158, 504-511. https://doi.org/10.1016/j.energy.2018.06.065

Mwasilu, F., Justo, J. J., Kim, E. K., Do, T. D., \& Jung, J. W. (2014). Electric vehicles and smart grid interaction: A review on vehicle to grid and renewable energy sources integration. Renewable and Sustainable Energy Reviews, 34, 501-516. https://doi.org/10.1016/j.rser.2014.03.031

Peng, C., Zou, J., \& Lian, L. (2017). Dispatching strategies of electric vehicles participating in frequency regulation on power grid: A review. Renewable and Sustainable Energy Reviews, 68(July 2015), 147-152. https://doi.org/10.1016/j.rser.2016.09.133

Resmi Gazete, 2018. Otopark Yönetmeliği (Say1:30340).

Resmî Gazete, 2019a, 1044 Sayılı Cumhurbaşkanı Kararı (Sayı: 30770), 2s. 
Resmî Gazete, 2019b, Elektrik Piyasasında Lisanssız Elektrik Üretim Yönetmeliği (Sayı: 30772), $16 s$.

Saygin, D., Ercumen, Y., Groote, M. De, \& Bean, F. M. (2019a). Enhancing Turkey's policy framework for energy efficiency of buildings, and recommendations for the way forward based on international experiences. (June).

Saygın, D., Tör, O., Teimourzadeh, S., Koç, M., Hildermeier, J., \& Kolokathis, C. (2019b). Türkiye ulaştırma sektörünün dönüşümü : Elektrikli araçların Türkiye dağıtım şebekesine etkileri. In SHURA Enerji Dönüşümü Merkezi. Retrieved from www.shura.org.tr

Shaukat, N., Khan, B., Ali, S. M., Mehmood, C. A., Khan, J., Farid, U., ... Ullah, Z. (2018). A survey on electric vehicle transportation within smart grid system. Renewable and Sustainable Energy Reviews, 81(May 2017), 1329-1349. https://doi.org/10.1016/j.rser.2017.05.092

Tuballa, M. L., \& Abundo, M. L. (2016). A review of the development of Smart Grid technologies. Renewable and Sustainable Energy Reviews, 59, 710-725. https://doi.org/10.1016/j.rser.2016.01.011

Türkiye Cumhuriyeti Enerji Piyasası Düzenleme Kurumu, Elektrik Tarifelerine Esas Tarife Tablolar1, https://www.epdk.org.tr/Detay/Icerik/3-1327/elektrik-

faturalarina-esas-tarife-tablolari (Erişim Tarihi: 08.10.2019).

Wang, H. J., Wang, B., Fang, C., Li, W., \& Huang, H. W. (2019). Charging Load Forecasting of Electric Vehicle Based on Charging Frequency. IOP Conference Series: Earth and Environmental Science, 237(6). https://doi.org/10.1088/1755-1315/237/6/062008

Yiğit Akü, Jel VRLA Derin Deşarj Aküler, https://www.yigitaku.com/wp-content/uploads/2018/07/12V200Ah-Jel-TR.pdf ( Erişim Tarihi: 30.08.2019).

Zheng, Y., Niu, S., Shang, Y., Shao, Z., \& Jian, L. (2019). Integrating plug-in electric vehicles into power grids: A comprehensive review on power interaction mode, scheduling methodology and mathematical foundation. Renewable and Sustainable Energy Reviews, 112(June), 424-439. https://doi.org/10.1016/j.rser.2019.05.059 